\title{
THE EMERGENCE OF WAGE DISCRIMINATION IN U.S. MANUFACTURING
}

\author{
by \\ Joyce Burnette * \\ Wabash College
}

CES 11-18

June, 2011

The research program of the Center for Economic Studies (CES) produces a wide range of economic analyses to improve the statistical programs of the U.S. Census Bureau. Many of these analyses take the form of CES research papers. The papers have not undergone the review accorded Census Bureau publications and no endorsement should be inferred. Any opinions and conclusions expressed herein are those of the author(s) and do not necessarily represent the views of the U.S. Census Bureau. All results have been reviewed to ensure that no confidential information is disclosed. Republication in whole or part must be cleared with the authors.

To obtain information about the series, see www.census.gov/ces or contact Cheryl Grim, Editor, Discussion Papers, U.S. Census Bureau, Center for Economic Studies 2K130B, 4600 Silver Hill Road, Washington, DC 20233, CES.Papers.List@census.gov. 


\begin{abstract}
This paper examines the hypothesis that wage discrimination emerged at the beginning of the twentieth century. I test for wage discrimination by estimating the female-male productivity ratio from samples of manufacturing firms in the northeast, and then comparing the estimated productivity ratio to the wage ratio. I find that women did not face wage discrimination in manufacturing during the nineteenth century. In 1900 there was wage discrimination against women in white-collar jobs, but not in blue-collar jobs. Wage discrimination persisted, and in 2002 the female-male wage ratio was less than the productivity ratio.
\end{abstract}

* I am grateful for all the help I received from many sources, including Jeremy Atack, Frank Howland, Peter Mikek, and participants in seminars at UC Davis, IUPUI, and Columbia University. Research assistance was provided by Samiul Haque, Andrew Sparks, and Spencer Sheridan. Some of the research for this paper was support by the McLain-McArnold-Turner Fellowship from Wabash College. The research involving the 2002 data was conducted while the author was a Special Sworn Status researcher of the U.S. Census Bureau at the Chicago Census Research Data Center. Any opinions and conclusions expressed herein are those of the author and do not necessarily represent the views of the U.S. Census Bureau. All results have been reviewed to ensure that no confidential information is disclosed. This research uses data from the Census Bureau's Longitudinal Employer Household Dynamics Program, which was partially supported by the following National Science Foundation Grants SES-9978093, SES-0339191 and ITR-0427889; National Institute on Aging Grant AG018854; and grants from the Alfred P. Sloan Foundation. 
In spite of the large body of research on labor market discrimination, we are just beginning to map out where and how discrimination operated in the past. Discrimination was not uniform in the past, but varied over time and place. Claudia Goldin suggested that wage discrimination emerged around the beginning of the twentieth century, but she presented only weak evidence for this claim. ${ }^{1}$ This paper provides better evidence to support her claim, using Census of Manufacturing data to test for wage discrimination from 1833 through 2002, and finding evidence of wage discrimination against women in the twentieth century, but not in the nineteenth century.

Economists do not always mean the same thing when they talk about "discrimination." Fortunately, the term "discrimination" usually does mean one of a few clearly defined types of discrimination. The two most important models of discrimination are Becker's wage discrimination model and Bergmann's occupational crowding model. This paper examines wage discrimination, which occurs if the relative wage paid to females is less than their relative productivity:

$$
\frac{w_{f}}{w_{m}}<\frac{M P_{f}}{M P_{m}} .
$$

Even if there is no wage discrimination, other forms of discrimination may exist. Barbara Bergmann's crowding model provides a model of discrimination that implies no wage discrimination. In the crowding model, women are allowed to enter occupation B, but not occupation A. Women are then "crowded" into occupation B, where the supply of workers is large relative to the demand. Because the marginal product of labor is declining, the large supply of worker in occupation B leads to a low marginal product of labor and thus a low wage. In occupation A, where the supply of worker is small relative to the demand, marginal product and wage are both high. In this model wages are equal to marginal product, so there is no wage discrimination, but women workers have a low marginal product because they are crowded into "female" jobs. The method I use will test for wage discrimination, but cannot detect the

\footnotetext{
${ }^{1}$ Goldin (1990) p. 83.

${ }^{2}$ Becker defined the market discrimination coefficient as $\frac{\pi_{w}}{\pi_{n}}-\frac{\pi_{w}^{0}}{\pi_{n}^{0}}$, where $\pi_{i}$ is the market wage and $\pi_{i}^{0}$ represents "the equilibrium wage rates without discrimination." Becker (1971), p. 17.
} 
presence of occupational crowding. Other studies will be needed to test for occupational crowding. ${ }^{3}$

While the fact that women have consistently earned less than men is easily observed, observers have interpreted this fact in very different ways. Jarrell and Stanley (2004, p. 282) claim that "Clearly, women experience significant discrimination in pay." Others, however, question this conclusion, claiming that differences between the genders in skills and preferences are sufficient to explain the entire wage gap. ${ }^{4}$ There is general agreement that differences in productivity explain at least a portion of the wage gap, but it remains unclear whether differences in productivity cause the entire wage gap because productivity is difficult to measure. Certainly the available data do not contain everything relevant for productivity. Potential experience is a poor measure of actual experience for women, and women are more likely to quit their jobs for personal reasons. ${ }^{5}$ Choices such as college major affect earnings. ${ }^{6}$ Women may have less effort to expend for their jobs if they have heavy family responsibilities. ${ }^{7}$ Psychological characteristics such as self-esteem also affect productivity. ${ }^{8}$ The difficulty of accurately measuring productivity differences has led some researchers to use audit studies, which control for unobserved differences by making men and women identical on paper. An audit study by Neumark, Bank, and Van Nort (1996) found that females were less likely to be hired at high-priced restaurants even when they had the same resumes as male applicants. Direct evidence also provides evidence of discrimination; for example, orchestras that introduced blind auditions hired more women. ${ }^{9}$

The causes of nineteenth-century wage gaps are also disputed. Some historians claim that female factory workers were underpaid. Layer $(1952$, p. 4, 167, 175) claimed that the labor market for textile workers was not competitive, and that both immigrants and females earned wages below the competitive level. Gitelman (1967, p. 233) claimed that female cotton factory workers were paid "a discriminatory wage rate." Other historians, however, claim that wages

\footnotetext{
3 I have tested for occupational crowding in eighteenth-century English agriculture, and I did not find any evidence of crowding there. See Burnette (1996).

${ }^{4}$ Christina Hoff Sommers, "Fair Pay Isn't Always Equal Pay," New York Times, Sept. 21, 2010.

${ }^{5}$ Keith and McWilliams (1995).

${ }^{6}$ Daymont and Andreisani (1984).

${ }^{7}$ Becker (1985).

${ }^{8}$ Goldsmith, Veum, and Darity (1997).

${ }^{9}$ Goldin and Rouse (2000).
} 
were not discriminatory. In her study of the Amoskeag Co., Hareven (1982, p. 282) claimed that "Textile work offered significant employment opportunities for women without wage discrimination." Paul David (1970, p. 550, 578) suggested that firms had monopsony power, and that in general worker were paid less than their marginal product, but assumed that the female-tomale wage ratio equaled the productivity ratio. Nickless (1976, p. 107) assumed no monopsony power, and suggested that wages were set at the competitive level. Vedder, Gallaway, and Klingaman (1978) measured the marginal productivity of workers in the cotton textile industry, and concluded that women's wages matched their marginal product in 1832. Rosenbloom and Sundstrom (2009) suggest that during the period between the Civil War and World War I labor markets were competitive. McGouldrick and Tannen (1980) concluded that gender wage discrimination appeared between 1910 and 1969 in the textile and clothing industries, but both their data and method have been criticized. ${ }^{10}$

Claudia Goldin concluded that wage discrimination by gender was not important in nineteenth-century manufacturing, but "emerged sometime between 1890 and 1940 in the whitecollar sector of the economy." "11 To support this conclusion she calculated the percentage of the wage gap explained by observable characteristics using the standard Oaxaca decomposition. To calculate the Oaxaca decomposition, the researcher uses individual-level data on wages to estimate separate wage equations for men and women. The coefficients from these equations can be used to decompose the difference in wages into an explained portion and an unexplained portion. ${ }^{12}$ The explained portion of the wage gap is the difference in observed characteristics, weighted by the coefficients from either the male or the female wage equation. The remainder of the wage gap is unexplained. Using this method, Goldin found that the unexplained portion of the wage gap "rose from at most 20 percent of the difference in male and female earnings in 1890 manufacturing, to 55 percent in office work in 1940."13

Unfortunately, the Oaxaca decomposition is a poor measure of wage discrimination. The unexplained portion of the wage gap is often interpreted as a measure of discrimination, though as Altonji and Blank (1999, p. 3156) note, "This is misleading terminology . . because if any important control variables are omitted that are correlated with the included Xs, then the B

\footnotetext{
${ }^{10}$ See Niemi (1982) and Thornton and Hyclak (1982).

${ }^{11}$ Goldin (1990) p. 89.

${ }^{12} \ln \bar{w}_{m}-\ln \bar{w}_{f}=\left(\bar{X}_{m}-\bar{X}_{f}\right)^{\prime} \beta_{m}+\bar{X}_{f}^{\prime}\left(\beta_{m}-\beta_{f}\right)$

${ }^{13}$ Goldin (1990) p. 117.
} 
coefficients will be affected." The unexplained portion of the wage gap contains not only wage discrimination, but also the effects of any omitted variables. If there are any unobserved variables that make women less productive than men, the unexplained portion of the wage gap will overestimate wage discrimination. Conversely, if there are any unobserved variables that make women more productive than men, the unexplained portion of the wage gap will underestimate wage discrimination. Since the explanatory variables cannot include all individual characteristics that might be important for productivity, a large portion of the wage gap may be unexplained simply because we do not have sufficient data to measure productivity, rather than because of discrimination. Often the unexplained portion of the wage gap is fairly large, suggesting a wide range of possible levels of wage discrimination, including no wage discrimination. ${ }^{14}$ While researchers recognize that the unexplained portion of the wage gap is not necessarily due to wage discrimination, sometimes they slip into calling it simply "wage discrimination." 15

Fortunately, there is a more accurate way to measure wage discrimination. Crosssectional firm data can be used to estimate production functions, and to directly estimate the productivity of female workers relative to male workers. This more accurate measure of productivity ratio can be compared to the wage ratio to test for wage discrimination. There is now a small but important body of literature that tests for wage discrimination using productivity estimates from production functions. Table 1 summarizes these studies, and demonstrates that the results are not uniform. Some of these studies are historical, and some use more recent data. Some studies conclude that there is wage discrimination, and some studies conclude that there is no wage discrimination. Studies of the last few decades suggest wage discrimination in the US, but not in other countries. Repeating such studies for different times and locations will allow us to begin to map historical changes in both relative female productivity and wage discrimination.

Using a more accurate measure of wage discrimination, this paper confirms Goldin's findings that there was little wage discrimination in the nineteenth century, but that such discrimination emerged in the twentieth century. Since the US labor market was not unified, I do not attempt to include all US manufacturing, but instead concentrate on the Northeast, which

\footnotetext{
${ }^{14}$ Joyce Jacobsen (1994), p. 317, reports that, in 1990, 71 percent of the gender wage gap was unexplained for whites, and 70 percent for nonwhites.

${ }^{15}$ See, for example Neumark (1988).
} 
contained the majority of US manufacturing firms through $1850 .{ }^{16}$ I find no evidence of wage discrimination between 1833 and 1880. By 1900, however, wage discrimination had appeared for white-collar women, though not for blue-collar women. While data is not available over the next 100 years, data from 2002 confirm the presence of wage discrimination in contemporary US manufacturing.

\section{Model}

This paper tests for wage discrimination by comparing the observed wage ratio to an estimated productivity ratio. Thus the estimation of the productivity ratio is central to this paper. This section describes the method used to estimate that ratio.

If we assume a Cobb-Douglas production function with homogenous labor, we could estimate the parameters of the production function by regressing the log of value added on the logs of the inputs. If labor were homogenous, the production function would be

$$
Q=A K^{a_{1}} L^{a_{2}}
$$

or

$$
\ln Q=\ln A+a_{1} \ln K+a_{2} \ln L
$$

where $\mathrm{Q}$ is the value of output, $\mathrm{K}$ is capital, and $\mathrm{L}$ is labor. If labor is not homogenous, however, we need a production function that includes more than one labor input. One possible way to incorporate different kinds of labor into the production function is to treat each type of labor as a separate input in the Cobb-Douglas production function and estimate a production function of the form

$$
\ln Q=\ln A+\beta_{1} \ln M+\beta_{2} \ln F+\beta_{3} \ln K
$$

where $\mathrm{M}$ is the number of male workers and $\mathrm{F}$ is the number of female workers. This was the method used by Vedder, Gallaway, and Klingaman (1978) to estimate productivity in US cotton textiles, by Cox and Nye (1989) to estimate productivity in nineteenth-century French manufacturing, and by Carden (2004) to estimate relative productivity in nineteenth-century US manufacturing. However, I find this method problematic. This production function assumes that

\footnotetext{
16 The Northeast includes Connecticut, Maine, Massachusetts, New Hampshire, New Jersey, New York, Pennsylvania, Rhode Island, and Vermont. In 1850 sixty percent of US manufacturing establishments were in the Northeast. See Dodd (1993). In 187045 percent were in the Northeast. On labor market integration see Wright (1986). While there was some convergence over the nineteenth century, Rosenbloom (1990) argues that the US labor market was still not integrated at the end of the century.
} 
the elasticity of substitution between male and female labor is one, and productivity ratios estimated in this way tend to be unstable. Vedder, Gallaway, and Klingaman estimate a femalemale productivity ratio of 0.16 in 1832 and 1.10 in 1860, quite a radical change over three decades. More importantly, this production function also assumes that both male and female workers are necessary for production; if the firm hires zero units of either type of labor, then it cannot produce any output. Since this assumption is obviously violated at many firms, I prefer a specification that allows firms to produce if they hire only one type of labor.

Leonard (1984) included a linear combination of two types of labor as the aggregate labor input in a Cobb-Douglas production function. He assumed the production function was of the form

$$
Q=e^{\alpha_{1}} K^{\alpha_{2}}\left(L_{A}+C L_{B}\right)^{\alpha_{3}}
$$

In this production function the two types of labor are perfect substitutes for each other, though not necessarily at a ratio of one-to-one. The parameter $\mathrm{C}$ measures the ratio of the marginal products of the two types of labor, which is a constant and does not depend on how many workers of each type are employed. This specification makes it easy to test whether female-male productivity ratio was equal to the wage ratio. The parameter $\mathrm{C}$ measures the ratio of the marginal product of a female to the marginal product of a male:

$$
\frac{d Q / d F}{d Q / d M}=C \text {. }
$$

While this nested Cobb-Douglas production function has many advantages, it cannot be estimated by a simple linear regression.

Various authors have used different techniques to estimate the nested model. Leonard used a Taylor-series approximation to make the non-linear equation (2) into the linear equation

$$
\ln Q=\alpha_{1}+\beta_{1} \ln K+\beta_{2} \ln L+\beta_{2}(C-1) P
$$

where $\mathrm{L}$ is the total number of workers employed, and $\mathrm{P}$ is the proportion that are female. Hellerstein and Neumark (1999) use the same approach to examine relative female productivity in Israeli manufacturing, and McDevitt, Irwin, and Inwood (2009) use this method to estimate relative female productivity in Canadian clothing factories. As Leonard notes, this approximation is closer to the true relationship when $\mathrm{P}$ is small and $\mathrm{C}$ is close to one. Since women were a large portion of the workforce in my data set, and I do not expect the productivity 
ratio to be close to one, equation (3) is probably not a good approximation of the non-linear relationship in nineteenth-century US manufacturing. An alternative is to estimate equation (2) directly using non-linear regression or maximum likelihood. Other studies have used variants of this approach. Hellerstein and Neumark (1995) estimate an expanded version of (2) with twelve kinds of labor categorized by age and occupation. Haegeland and Klette (1999) use maximum likelihood to estimate the parameters of a nested translog production function. I will use nonlinear least squares to estimate the production function.

The Cobb-Douglas production function is a special case of the translog production function. To avoid the simplifying assumptions inherent in the Cobb-Douglass production function, this paper will use a nested translog production function. The translog function with three factors of production is

$$
\begin{aligned}
\ln Q= & a_{0}+a_{1} \ln K+a_{2} \ln L+a_{3} \ln R M+a_{4} \ln K^{2}+a_{5} \ln L^{2}+a_{6} \ln R M^{2}+a_{7} \ln K \ln L \\
& +a_{8} \ln K \ln R M+a_{9} \ln L \ln R M
\end{aligned}
$$

where RM is raw materials. This function becomes the Cobb-Douglass function if $a_{4}=a_{5}=a_{6}=a_{7}=a_{8}=a_{9}=0$. For the case where there are two types of labor, $\mathrm{M}$ and $\mathrm{F}$, the aggregate labor input is

$$
L^{*}=M+b_{1} F
$$

where $\mathrm{L}^{*}$ is the aggregate labor input, $\mathrm{M}$ is the number of men, $\mathrm{F}$ is the number of women. The production function becomes:

$$
\begin{aligned}
\ln Q= & a_{0}+a_{1} \ln K+a_{2} \ln \left(M+b_{1} F\right)+a_{3} \ln R M+a_{4} \ln K^{2}+a_{5} \ln \left(M+b_{1} F\right)^{2}+a_{6} \ln R M^{2} \\
& +a_{7} \ln K \ln \left(M+b_{1} F\right)+a_{8} \ln K \ln R M+a_{9} \ln \left(M+b_{1} F\right) \ln R M
\end{aligned}
$$

If there are more than two categories of labor, then equation 4 is expanded to include the additional categories of labor. In equation (5) the parameter $b_{1}$ measures the ratio of the marginal product of a female to the marginal product of a male. The specification assumes that men and women are perfect substitutes, though not necessarily at a one-for-one ratio. This is reasonable if women and men can be used for the same tasks, but men produce more output per hour, or can tend a greater number of machines, than women.

The economic history literature has generally favored this specification of the production function, though usually the parameter $b_{1}$ is assumed rather than estimated. Most studies that 
have estimated production functions for nineteenth-century manufacturing calculate an aggregate labor measure by weighting each type of labor by its relative wage, under the assumption that wages are an accurate measure of productivity. When aggregating the amount of labor used by manufacturing firms, Sokoloff (1986, p. 702-3) counts an adult woman as the equivalent of half an adult man because women's wages were about half of men's wages.

Females and boys have been treated as equal, in terms of their labor input, to one-half of an adult male employee, with these weights having been drawn from evidence on the relative wages of the groups prevailing near the end of the period.

In a comment on this article, Jeffrey Williamson (1986) questions whether assuming a constant productivity ratio over time is valid, but does not question the assumption that the wage ratio is an accurate measure of the productivity ratio. Similarly, Atack, Bateman, and Margo (2003) assume, based on the wage ratio, that an adult female worker is equal to 60 percent of an adult male worker in US manufacturing in $1880 .^{17}$ Ulrich Dorazelski (2004) also constructed a composite labor measure using the wage ratios to weight female and child labor in his study of French manufacturing. By estimating the productivity weights, the current paper tests the assumption that the wage ratio matches to productivity ratio.

Following Aigner, Lovell, and Schmidt (1977), the error term for a production function is often assumed to have two components, a random error term and an inefficiency term:

$$
y_{i}=f\left(x_{i} ; \beta\right)+v_{i}+u_{i}
$$

where $v_{i}$ is a normally distributed error term (such as measurement error) and $u_{i}$ is a nonpositive error term that indicates if a firm is operating below the production frontier. While (6) can be estimated by maximum likelihood if an assumption is made about the distribution of $u$, only the constant term will be biased if the function is estimated by OLS. ${ }^{18}$ Since I am not concerned with either the constant term or the efficiency of a particular firm, OLS is sufficient for my purposes.

\footnotetext{
17 See also Atack, Bateman, and Margo, 2005.

18 "if estimation of $\beta$ alone is desired, all but the coefficient in b corresponding to a column of ones in $\mathrm{X}$ is estimated unbiasedly and consistently by least squares.” Aigner, Lovell, and Schmidt, 1977, p. 28.
} 


\section{McLane Report}

The earliest data used in this paper is from a 1833 report to the U.S. House of Representatives titled Documents relative to the Manufactures in the United States, also known as the McLane Report because the Secretary of the Treasury Louis McLane collected the returns. The report was published in 1833, but the data was submitted in the spring of 1832. Sokoloff (1986) used data from the McLane Report and from the 1850 and 1860 censuses to estimate total factor productivity in manufacturing. Goldin and Sokoloff (1982) use the McLane Report and the 1850 census to examine the employment and wages of female manufacturing workers. The McLane report includes data on smaller workshop-type establishments, as well as the more modern factories, though smaller firms are under-represented. Goldin and Sokoloff (1982, p. 745) report that the main defect of the data source is that it is not a representative sample of firms either geographically or in terms of firm size. Neither issue is likely to bias my estimates of relative female productivity.

For the purposes of this paper I have collected a data set of all firms in Massachusetts with complete information on the output, capital, raw materials, and labor. ${ }^{19}$ In some cases the McLane report lists more than one factory together. For example, in Adams, Massachusetts, "2 calico factories" together produced 1.15 million yards of cloth and hired 38 men, 14 boys, and 10 women and girls. In this case the observation includes the aggregate for both firms. The "singles" samples include only observations that are clearly for one firm only, and the full sample includes all observations. Using observations where multiple firms have been aggregated is not ideal, but data limitations will require me to do so later in the paper, so here I demonstrate that the results from both data sets are similar. Since production functions may not be uniform across industries, I also estimate production functions for two specific industries, textiles and shoes. For these industries I do not confine my sample to Massachusetts but collect data from all the states in the McLane Report. Table 2 shows descriptive statistics for all four samples.

The McLane Report lists the number of workers employed in three categories: "Average number of males over 16 years old employed", “Average number of boys under 16 years of age", and "Average number of women and girls employed." This allows me to estimate the productivity of three separate categories of workers: men, boys, and females. The "female" category includes both adult women and girls, which may affect the relative productivity of this

\footnotetext{
${ }^{19}$ I have also excluded firms which report negative value added or zero capital.
} 
group. Wages are reported separately for men, boys, and females, and explicitly state that they are wages for workers "boarding themselves." Wages are not reported for every firm in every category because not every firm hired all three types of labor. The average wage for each type of labor, then, is based on data collected from less than the full sample of firms. I calculate the female-to-male wage ratio for each observation that reports both wages. The average is 0.41 , which is the same as wage ratio that Goldin and Sokoloff report for the McLane Report. ${ }^{20}$ Boys earned 43 percent as much as men. The employment of women was particularly high in the textile industry. The greater employment of females in textiles is consistent with other evidence; Thomas Dublin's study of Hamilton Manufacturing Company in Lowell found that 85 percent of the workforce was female. ${ }^{21}$

I use this data to estimate the equation

$$
\begin{aligned}
& \ln Q_{i}=\ln C+a_{K} \ln K_{i}+a_{R M} \ln R M_{i}+a_{L} \ln \left(M_{i}+b_{1} F_{i}+b_{2} B_{i}\right)+a_{K K} \ln K_{i}^{2} \\
& +a_{R M R M} \ln R M_{i}^{2}+a_{L L} \ln \left(M_{i}+b_{1} F_{i}+b_{2} B_{i}\right)^{2}+a_{K R M} \ln K_{i} * \ln R M_{i} \\
& +a_{K L} \ln K_{i} * \ln \left(M_{i}+b_{1} F_{i}+b_{2} B_{i}\right)^{2}+a_{R M L} \ln R M_{i} * \ln \left(M_{i}+b_{1} F_{i}+b_{2} B_{i}\right)+\varepsilon_{i}
\end{aligned}
$$

using non-linear regression; Table 3 presents the results. The first column presents the results using only observations that are clearly for a single firm. The results suggest that females were 37 percent as productive as adult males, and boys were 39 percent as productive. The estimation in the second column includes an adjustment for entrepreneurial labor. Sokoloff (1986, p. 686) calculated the aggregate labor input (total employment) as:

$$
\mathrm{TE}=\mathrm{M}+0.5(\mathrm{~F}+\mathrm{B})+\mathrm{E}
$$

where $\mathrm{M}$ is the number of men, $\mathrm{F}$ is the number of females, $\mathrm{B}$ is the number of boys, and $\mathrm{E}$ is equal to one. This equation adds one male-equivalent worker for the contribution of the entrepreneur, who presumably worked at the firm but was not counted as an employee. Using this adjustment does not substantially change the results; in this estimation females are 34 percent was productive as adult men, and boys are 40 percent was productive. The third column uses the full sample, including observations that aggregate multiple firms together. Here the estimate of relative female productivity is slightly higher, at 45 percent of adult male

${ }^{20}$ Goldin and Sokoloff (1982), p. 760. Note that the average of the ratios $(0.41)$ is different from the ratio of the average wages $(0.38 / 1.00=0.38)$ because fewer observations are used for the former.

${ }^{21}$ Thomas Dublin (1979), p. 26. 
productivity. The fourth and fifth columns look at individual industries. Productivity ratios in the textile industry were quite close to those for manufacturing as a whole. In the boot and shoe industry women were less productive, and boys more productive, than in manufacturing as a whole.

All of the coefficients suggest that both females and boys were less productive than adult males. To test for wage discrimination, we need to compare the estimated productivity ratios to the observed wage ratios. Table 3 reports p-values for the one-tail test of the hypothesis that the productivity ratio is less than or equal to the wage ratio. If the productivity ratio is significantly greater than the wage ratio, then there is wage discrimination. We cannot reject the null hypothesis in any case. I also test the joint hypothesis that $b_{1}=0.41$ and $b_{2}=0.43$. I estimate a restricted model with aggregate labor equal to

$$
\mathrm{L}^{*}=\operatorname{men}+(0.41 * \text { females })+(0.43 * \text { boys }) \text {. }
$$

I cannot reject the null hypothesis that the restricted model is a good fit. ${ }^{22}$ This is essentially a test of whether the standard method of measuring aggregate labor, which is to use relative wages to weight the different labor inputs as in equation (8):

$$
M+\frac{w_{f}}{w_{m}} F+\frac{w_{b}}{w_{m}} B
$$

is justified. My findings suggest that such a measure of aggregate labor is a good measure of labor input.

Altonji and Blank (1999, pp. 3197-8) criticize the estimates of Hellerstein, Neumark, and Troske by noting that firms may choose different gender division of labor as a result of differences in technology: "the variation across establishments in the makeup of the work force, particularly in the gender and skill mix, is likely to result mainly from heterogeneity in production technology." If being more productive causes firms to hire fewer females, then females might appear to be less productive than they really are. To check for a relationship between productivity and the gender mix of the labor force, I regress the percentage of the firm's labor force that is female on residuals from the first regression in Table 3. More productive firms would have higher-than-expected output, and thus would have positive residuals. Regression yields the following result:

${ }^{22} \mathrm{~F}(2,725)=0.34$. 


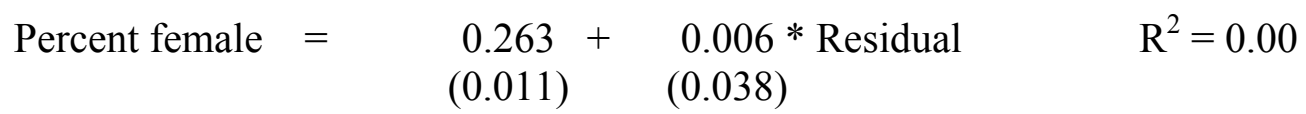

The R-squared suggests that there is no relationship between the residuals and the percentage of the labor force that is female, which suggests that there is no systematic relationship between firm productivity and the gender mix of the labor force.

\section{0 and 1860 Census of Manufacturing}

Next I examine manufacturing in the Northeast using samples of the nineteenth-century censuses of manufacturing compiled by Atack, Bateman and Weiss. ${ }^{23}$ Data from the manufacturing censuses have been used by economic historians to study firm productivity. Craig and Field-Hendrey (1993) used the 1860 census of to compare productivity in Northern and Southern manufacturing to productivity in agriculture. Atack, Bateman, and Margo (2003) used the 1880 census to examine the relationship between output and the length of the working day, and Atack, Bateman, and Margo (2004) showed that skill intensity (as measured by average wage) decreased with firm size. Because the categories used to report labor changed between 1860 and 1870, I will discuss the results from the manufacturing censuses in two parts. This section will report the results for 1850 and 1860, and the next section will report the results for 1870 and 1880.

The censuses report the value of output, the value of raw materials used, the total capital invested, and the number of workers. The 1850 and 1860 censuses report the number of workers in only two categories, males and females. Table 4 shows descriptive statistics for the 1850 and

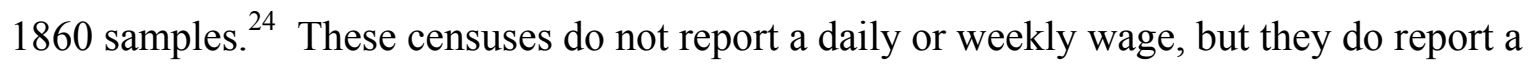
monthly wage bill for male and female workers. I calculate the average monthly wage for each type of worker by dividing the monthly wage bill by the number of workers at the firm. The result is noisier than a direct measure of wages, but does give an average wage ratio for the same firms as are used to estimate productivity. The average ratio of female-to-male wages was 0.48 in 1850 and 0.53 in 1860 .

To estimate the relative productivity of female workers in 1850 and 1860 , I estimate the following equation by non-linear least squares:

\footnotetext{
23 I use the state samples and include data from states in the Northeast.

24 The state samples are meant to be used at the state level, and are not weighted appropriately for regional analysis, so these averages should not be interpreted as averages for the region.
} 


$$
\begin{aligned}
& \ln Q_{i}=\ln C+a_{K} \ln K_{i}+a_{R M} \ln R M_{i}+a_{L} \ln \left(M_{i}+b_{1} F_{i}\right)+a_{K K} \ln K_{i}^{2}+a_{R M R M} \ln R M_{i}^{2}+a_{L L} \ln \left(M_{i}+b_{1} F_{i}\right)^{2} \\
& +a_{K R M} \ln K_{i}^{*} \ln R M_{i}+a_{K L} \ln K_{i}^{*} \ln \left(M_{i}+b_{1} F_{i}\right)^{2}+a_{R M L} \ln R M_{i} * \ln \left(M_{i}+b_{1} F_{i}\right)+\varepsilon_{i}
\end{aligned}
$$

Results are given in Table 5. The first and fourth columns provide the basic estimation described by equation (9). In the second and fifth columns I add one to the number of men, to account for the labor of the entrepreneur. The estimated productivity ratios are slightly higher than the wage ratios, but the differences are not statistically significant. Overall the estimates for 1850 and 1860 provide no evidence of wage discrimination. The third and sixth columns of Table 5 examine the textile industry. Estimates for 1860 suggest that productivity was higher in the textile industry than in other industries.

Comparing these estimates to Table 3, we notice an upward trend in the relative productivity of females. This trend seems ot be especially pronounced in the textile industry, and by 1860 females were 90 percent as productive as males. The large literature on labor productivity in textiles may provide some clues about why the productivity ratio rose. During the mid-nineteenth century there was an increase in overall labor productivity in textiles. Lazonick and Brush (1985) attribute this increase to intensification of work. They note that the native "farm girls" employed in the 1830s could easily quit in response to unfavorable working conditions, while the immigrant workers that became more common in the 1850 s did not have the same outside opportunities and were less able to quit.

Reports from female textile workers do suggest that those employed later in the century seem to have worked harder than those earlier in the century. Harriet Robinson, who wrote a memoir at the end of the nineteenth century, remembered that when she worked in the mills in the 1840 s the job was not overly taxing:

Though the hours of work were long, they were not over-worked; they were obliged to tend no more looms and frames than they could easily take care of, and they had plenty of time to sit and rest. I have known a girl to sit idle twenty to thirty minutes at a time. They were not driven, and their work-a-day life was made easy. ${ }^{25}$

However, the factory workers that she interviewed later in the century did not find their job so easy:

25 Robinson (1976), p. 43. 
The hours of labor are now less, it is true, but the operatives are obliged to do a far greater amount of work in a given time. They tend so many looms and frames that they have no time to think. They are always on the jump; and so have no opportunity to improve themselves. ${ }^{26}$

Robinson's impression is that the work of a female factory hand was greatly intensified.

James Besson, however, does not think the power of the employers changed that much, and attributed most of the increase productivity between 1835 and 1855 to increases in human capital. More skilled workers could achieve higher utilization rates, because the could attend to stops more quickly and effectively. In the 1830s each weaver attended two looms, but over the course of the century this increased, and by 1902 the average worker attended seven looms. ${ }^{27}$ Bessen concludes that, while some of this increase was the result of innovations, some of it was the result of the increased skills of the workers. Because it might take workers up to a year to reach the highest possible utilization rates for the machines, turnover was an important part of workers productivity.

These improvements in productivity should have affected female productivity more than male productivity. In the early period production workers were almost exclusively female, so improvements in the productivity of production workers would have affected women more than men. If productivity increased faster among female weavers than among male overseers and mechanics, either due to intensification of work or to human capital acquisition, then we would expect the female/male productivity ratio to rise. Another reason for rising relative female productivity was the changing composition of the labor force. After 1840 more immigrant men were hired as weavers, a job which had previously been all-female. Gitelman (1967) suggests that this employment pattern, and the lower wage or Irish men, was a result of discrimination. ${ }^{28}$ He claims that Irish males "were more strongly discriminated against within the firm than were females. Most were consigned to the lowest paying, dirtiest jobs." While discrimination is one possible explanation for this pattern, it is also possible that Irish men were hired for the lowerpaying jobs because they had fewer skills than native men. If this were so, then an increase in the percentage of male workers that were immigrants would reduce average male productivity and increase the female-male productivity ratio.

\footnotetext{
${ }^{26}$ Robinson (1976), p. 121-2.

${ }^{27}$ Bessen (2008), Figure 2.

${ }^{28}$ Gitleman, 1967, p. 251.
} 
The productivity and wage ratios in textiles diverge between 1850 and 1860, suggesting the possibility of wage discrimination. Relative female productivity increased to 90 percent, while the relative female wage remained at 60 percent. Though the difference is not statistically significant, Vedder, Gallaway, and Klingaman (1978) previously found evidence of wage discrimination in cotton textiles in 1860. If discrimination did arise in the textile industry, what could have caused this industry to be different from others? One hypothesis is that wage discrimination may have been related to the size of firms, with wage discrimination appearing in largest firms. This hypothesis is easily tested. Using data from 1860, I split the sample at the median into large and small firms using three measures of firm size: output, capital, and total employment. In each case relative female productivity was smaller at large firms than at small firms, suggesting that the high female productivity in the textile industry is not simply due to the fact that the industry had large firms. Wages were set in the market, so it is possible that textile firms found themselves in a situation where female productivity was very high, but they could still pay market rates determined by lower productivity elsewhere. However, if this was the case then textile firms should have hired only women, and should have hired women up to the point there their marginal product declined enough to equal the wage.

\section{0 and 1880 Censuses of Manufacturing}

National samples from the census of manufacturing are also available for 1870 and $1880 .^{29}$ These censuses present additional challenges in the way that labor and wages are reported. The 1870 and 1880 censuses report labor in three categories. Males over age 16 are included in the category "men", and females over age 15 are included in the category "women." "Children" includes younger workers of both sexes. The 1870 and 1880 censuses report an aggregate wage bill, but not wage bills by gender, so wage ratios can only be estimated.

Table 6 reports descriptive statistics for the 1870 and 1880 samples of the Northeast. The percentage female is not directly comparable across the samples because the category "women" contains all females in 1850 and 1860, and only females over age 15 in 1870 and 1880. Between 1870 and 1880 the employment of females was steady, but the employment of children fell. Women and children together were 37 percent of the labor force in 1870 and 30 percent in 1880. The 1870 census reports the number of months of operation, and the 1880 census reports the

\footnotetext{
${ }^{29}$ Atack, Bateman, and Weiss (2004).
} 
number of months the firms operated at fill-time, three-quarters time, two-thirds time, and halftime. Since a firm operating for six months should produce only half the output of a firm with the same capital and labor operating a full year, I adjust output and materials to a full-year equivalent by dividing each variable by the percentage of the year the firm is in operation. The 1880 census also reports the number of hours of work per day. The usual number of hours per day is 10 , so I adjust the each labor input to the equivalent of a ten-hour day. Thus, the number of men is the number of men reported by the census times hours per day divided by ten.

Because these data sets have three categories of workers, I modify the equation by making aggregate labor a function of men, women, and children hired. I use non-linear least squares to estimate the equation:

$$
\begin{aligned}
& \ln Q_{i}=\ln C+a_{K} \ln K_{i}+a_{R M} \ln R M_{i}+a_{L} \ln \left(M_{i}+b_{1} F_{i}+b_{2} C_{i}\right)+a_{K K} \ln K_{i}^{2} \\
& +a_{R M R M} \ln R M_{i}^{2}+a_{L L} \ln \left(M_{i}+b_{1} F_{i}+b_{2} C_{i}\right)^{2}+a_{K R M} \ln K_{i} * \ln R M_{i} \\
& +a_{K L} \ln K_{i} * \ln \left(M_{i}+b_{1} F_{i}+b_{2} C_{i}\right)+a_{R M L} \ln R M_{i} * \ln \left(M_{i}+b_{1} F_{i}+b_{2} C_{i}\right)+\varepsilon_{i} .
\end{aligned}
$$

Here $\mathrm{F}$ is the number of adult females, $\mathrm{C}$ is the number of children, and the other variables are defined as above. Table 7 gives the results of estimating this equation for 1870 and 1880. As in Table 4, I add a male worker to represent the entrepreneur, but this does not substantially change the results. The estimates for 1870 suggest that women were about 58 percent as productive as adult men, and children not productive at all. For 1880 the estimate of relative female productivity rose slightly to 70 percent, but the estimate of children's productivity jumps up to around 80 percent. The relative productivity of children may rise because of a reduction in the employment of very young children, but I do not place much weight on the estimates of child productivity because of the instability of the estimates and the low number of children employed.

Unfortunately the 1870 and 1880 census samples do not contain estimates of male and female wages. They do contain a total wage bill, so I attempt to estimate wages by regressing the total wage bill on the number of workers of each type. If firms were price-takers, wages would be constant across firms, and I should be able to reconstruction wages by examining the relationship between the number of workers of each type and the total wage bill. To estimate the wage ratios, I estimate the following equation:

$$
\ln w=\alpha+\beta P_{f}+\gamma P_{c}
$$

where $P_{f}$ is the percentage of the workforce that are women, and $P_{c}$ is the percentage of the workforce that are children, and $w$ is the average wage per worker (total wage bill/number of 
workers). A firm that hired only men should have an average wage of $\alpha$, and a firm that hired only women would have an average wage of $\alpha+\beta$, so

$$
\ln w_{f}-\ln w_{m}=\ln \frac{w_{f}}{w_{m}}=\beta
$$

and

$$
e^{\beta}=\frac{w_{f}}{w_{m}} .
$$

Since errors from the wage equation are likely to be correlated with errors from the production function, I jointly estimate the production and wage functions. Table 8 shows the estimated productivity coefficients and the coefficients from the wage equations. The estimates of relative female and child productivity are similar to the estimates in Table 7. Wages are not very well estimated; the regressions with neither location nor industry controls have very low R-squareds. Table 8 suggests that women were overpaid, but the estimated wage ratio is higher than typical estimates of the female-male wage ratio, suggesting that the problem may be in the estimation of the wage ratio. ${ }^{30}$ The estimates suggest that children were over-paid in 1870 and under-paid in 1880 , but the productivity ratios for children are not robust enough to create great confidence in this result.

\section{Census of Manufactures}

While aggregate data is not ideal for production functions, it is all that exists for the period after 1880. Manuscript census forms of the censuses of manufacturing for 1890 through 1920 were destroyed. This section will estimate production function based on aggregate inputs and outputs for state/industry cells in the 1900 census of manufactures. Other researchers have used industry aggregates of the censuses of manufacturing. Field-Hendrey (1998) used statelevel aggregates to estimate productions function in manufacturing.

Data from the 1900 census of manufacturing are not completely typed in, and currently I have 1443 observations from the Northeast, where each observation is a state/industry cell. Table 9 summarizes the data. States are not reported individually if the number of establishments in the state/industry cell is less than three. On average there are 130 establishments per

\footnotetext{
${ }^{30}$ Goldin (1990, p. 60) reports a ratio of 0.56 for 1885 . Wright (1885, p. 23) reports a ratio of 0.51 for Massachusetts in 1883.
} 
observation. For the production functions I convert all the data into averages per establishment. Wages are reported as the total annual spending on workers in each category. I divide total spending by the number of workers reported to obtain the average annual earnings of workers in each category.

The 1900 census of manufactures reported labor in seven different categories. The number of proprietors and "officers of corporation" were reported, but not by gender. White collar workers, designated as "General superintendents, managers, clerks, etc." were reported in two categories, men and women. Wage-earners were separated from the salaried white-collar employees, and were reported in three categories, men, women, and children. Some modern studies find that white-collar and blue-collar workers are complements, so I will not assume that all forms of labor are substitutes, but will treat white-collar and blue-collar workers as two different kinds of inputs. ${ }^{31}$ I define aggregate white-collar labor as

$$
W C=\mathrm{b}_{1} \text { Proprietors }+\mathrm{b}_{2} \text { Officers }+M W C+\mathrm{b}_{3} F W C
$$

where MWC is male managers and clerks, FWC is female managers and clerks. I define aggregate blue-collar labor as

$$
B C=M+b_{1} F+b_{2} C
$$

As above, I assume that these functions are nested in a translog production function. Since there are now two kinds of labor inputs, there are four different kinds of inputs. Table 10 gives the results of estimating both translog and Cobb-Douglass functions. The translog function is:

$$
\begin{aligned}
& \ln Q_{i}=\ln C+a_{K} \ln K_{i}+a_{R M} \ln R M_{i}+a_{W C} \ln \left(W C_{i}\right)+a_{B C} \ln \left(B C_{i}\right)+a_{K K} \ln K_{i}^{2}+a_{R M R M} \ln R M_{i}^{2} \\
& +a_{W C W C} \ln \left(W C_{i}\right)^{2}+a_{B C B C} \ln \left(B C_{i}\right)^{2}+a_{K R M} \ln K_{i}^{*} \ln R M_{i}+a_{K W C} \ln K_{i}^{*} \ln \left(W C_{i}\right)+a_{K B C} \ln K_{i}^{*} \ln \left(B C_{i}\right) \\
& +a_{R M W C} \ln R M_{i} * \ln \left(W C_{i}\right)+a_{R M B C} \ln R M_{i} * \ln \left(B C_{i}\right)+a_{W C B C} \ln \left(B C_{i}\right) * \ln \left(W C_{i}\right)+\varepsilon_{i}
\end{aligned}
$$

where $\mathrm{WC}$ and $\mathrm{BC}$ are defined as above. The Cobb-Douglass function is:

$$
\ln Q_{i}=\ln C+a_{K} \ln K_{i}+a_{R M} \ln R M_{i}+a_{W C} \ln \left(W C_{i}\right)+a_{B C} \ln \left(B C_{i}\right)+\varepsilon_{i}
$$

The second and forth columns include dummy variables for each state.

For blue-collar workers the results are quite similar to the results for 1870 . Women are about half as productive as men, and children are so unproductive we cannot reject the hypothesis that they have a marginal product of zero. There is no evidence of wage discrimination against women or children in blue-collar work. The estimates for white-collar

31 Hammermesh (1993), pp. 110-111. 
workers, however, do suggest wage discrimination. The relative productivity of female whitecollar workers is not robust to the specification used, but suggests that women were at least as productive as men, and possibly more productive. In three of the four specification reject the null hypothesis of no wage discrimination is rejected. Female white-collar workers seem to have earned only half as much as their male counterparts, even though they were at least as productive as the men. These results suggest that by 1900 wage discrimination had appeared in white-collar work, though not yet in blue-collar work.

\section{Census of Manufactures}

Unfortunately it becomes more difficult to estimate the productivity ratio in the twentieth century. Individual-level data is closed for 72 years, so publically-available data is limited to industry aggregates after the 1930s. More importantly, though, the Census of Manufactures and the Annual Survey of Manufactures do not collect information on employment by gender. Because of these limitations, studies of the twentieth-century US have used data that is less than ideal. Leonard (1984) used industry aggregates, and Hellerstein, Neumark, Troske (1999) used firms that were unique in an industry/location cell. Fortunately, I was able to obtain access to firm-level Census of Manufactures data for 2002 and link it to demographic data on workers from the Longitudinal Employer-Household Dynamics (LEHD) data files. ${ }^{32}$

The 2002 Census of Manufactures contains information on the value of output, the total costs of materials, total assets at the beginning of the period, and the total number of workers. Firm identification numbers were used to link the Census of Manufactures records to records of individual workers from LEHD data. By aggregating all the workers linked to the same firm, I am able to determine the gender composition of the firm's workforce. The link was not good enough to match every worker, so I used aggregates from the LEHD to obtain the percentage of workers who were female, but I used the Census of Manufactures records for total employment. Thus, the number of female workers at each firm was calculated as $F=p_{f} E$, where $E$ is total employment recorded in the Census of Manufactures, and $\mathrm{p}_{\mathrm{f}}$ is the percentage of workers at the firm who were female, and is obtained from the LEHD data files. LEHD files are only available for certain states, so instead of limiting the data to the Northeast I used all available data.

\footnotetext{
32 This work was done at the Chicago Census Research Data Center.
} 
I estimated two different equations. The first included only two categories of labor, male and female (as equation 9), and the second divided each gender into three age groups, creating six categories of labor. Thus I estimated

$$
\begin{aligned}
\ln Q_{i}= & a_{0}+a_{1} \ln K_{i}+a_{2} \ln L_{i}^{*}+a_{3} \ln R M_{i}+a_{4} \ln K_{i}^{2}+a_{5} \ln L_{i}^{* 2}+a_{6} \ln R M_{i}^{2}+a_{7} \ln K_{i} \ln L_{i} \\
& +a_{8} \ln K_{i} \ln R M_{i}+a_{9} \ln L_{i} \ln R M_{i}+\varepsilon_{i}
\end{aligned}
$$

where

$$
L_{i}^{*}=M_{i}+b F_{i}
$$

or

$$
L_{i}^{*}=b_{1} M_{Y i}+M_{M i}+b_{2} M_{O i}+b_{3} F_{Y i}+b_{4} F_{M i}+b_{5} F_{O i}
$$

where the subscript $\mathrm{Y}$ indicates worker below age 25, $\mathrm{M}$ indicates men age 25 to 34, and $\mathrm{O}$ indicates workers age 55 and older.

Table 11 shows the female-male ratio of average wages and the estimated productivity ratios. The results indicate that, for women overall and for each age category, women were less productive than men, but were still underpaid. These results are consistent with the results of Leonard (1984) and Hellerstein, Neumark, Troske (1999) who also found evidence of wage discrimination in US manufacturing. The extent of gender wage discrimination seems to rise as workers age. Both male and female workers are underpaid when young, but males are overpaid when old, while females remain underpaid throughout their lives. As a result, the gender wage ratio is similar to the productivity ratio for young workers, while wage discrimination is greatest for older workers. This pattern is consistent with a labor market where men are more likely to be hired into internal labor markets that overpay older workers. ${ }^{33}$

\section{Trends}

The varying definitions of the labor categories make it difficult to examine changes over time in relative female productivity. However, with some adjustments we can produce productivity estimates that are reasonably comparable over time. For 1833, 1850, and 1860 the category "female" contained females of all ages, including girls. Males are separated into men and boys in 1832, but they can easily be re-combined, producing a female/male productivity ratio comparable to those for 1850 and 1860 . For 1870 and after, the category "children" contains

\footnotetext{
${ }^{33}$ Goldin (1990) p. 117.
} 
both boys and girls, making it impossible to know the total number of female workers.

However, making different assumptions about the percentage of children that were female would provide a range of possible values for the female-to-male productivity ratio. The two possible extremes are that all children were boys, and that all children were girls. In Table 12 I reestimate the production functions making both of these extreme assumptions. The first and third columns assume that all children were girls, and add the number of children to the number of women. The second and fourth columns assume that all children were boys, and add the number of children to the number of men. The estimates of relative female productivity under both of these assumptions should provide bounds for the possible values of the female-to-male productivity ratio. To make estimates for 1900 comparable to earlier estimates, I combine whitecollar and blue collar workers together, creating only three kinds of labor, men, women and children. As for 1870 and 1880, I estimate two ratios, one assuming all children are male and one assuming all children are female.

The results suggest that relative female productivity was somewhere between 0.36 and 0.52 for 1870 , and somewhere between 0.72 and 0.73 for 1880 . These estimates suggest that relative female productivity in manufacturing increased substantially between 1833 and 1880 . Between 1880 and 1900, however, there seems to be a fall in relative female productivity. The wage ratio generally follows this pattern, rising between 1833 and 1880, and then falling. However, the fall in the wage ratio between 1880 and 1900 is large enough that by 1900 there is evidence of wage discrimination. Consistent with Goldin's claim, wage discrimination appears at the dawn of the $20^{\text {th }}$ century. Also consistent with Goldin's story is the fact that the wage discrimination appears in white-collar rather than blue-collar work.

Figure 1 graphs the female-male productivity and wage ratios. For 1870-1900 there are two estimates for each, depending on whether children are counted as males or females. While the estimates are noisy, there does appear to be an upward trend in both wages and productivity.

\section{Conclusion}

Since men and women were not equally productive, we can only test for wage discrimination if we are able to measure the productivity ratio. The estimates of relative productivity provided in this paper add to a small body of evidence on the male-female productivity ratio. Table 13 compares the wage and productivity ratios in this paper to results 
from various other papers that estimate relative female productivity. While wage discrimination may have appeared earlier in certain industries such as textiles, manufacturing as a whole was not characterized by wage discrimination in the nineteenth century. Wage discrimination seems to have emerged by 1900 for white-collar women, though blue-collar women were still paid wages commensurate with their productivity. Of course, even when there was no wage discrimination, there may have been discrimination in other forms. If women were confined to low-productivity occupations, then discrimination worked by lowering their productivity.

Over time, though, wage discrimination appeared in US manufacturing. By the later half of the twentieth century, women in manufacturing experienced wage discrimination. Leonard finds evidence of wage discrimination in 1966 and 1977, ${ }^{34}$ and Hellerstein, Neumark, and Troske find evidence of wage discrimination in 1990. In contrast to Norway and Israel, where there is no evidence of wage discrimination, US women do seem to have been underpaid in late twentieth-century US manufacturing. This leads to the question of why wage discrimination emerged.

When Claudia Goldin found that wage discrimination increased between the nineteenth and twentieth centuries, she attributed this change the rise of internal labor markets. She described the nineteenth century as characterized by spot markets: "Manufacturing jobs and many others in the nineteenth century were part of what I shall terms the 'spot market.' Workers were generally paid their value to the firm at each instant, or what economists call the value of labor's marginal product." 35 This changed in the twentieth century as internal labor markets replaced spot markets, and women in occupations such as clerical work found their wages limited by the lack of opportunity for advancement. This hypothesis connects the emergence of wage discrimination to changes in the economy that seem to have resulted from the increased importance of firm-specific human capital.

For most of the nineteenth century, manufacturing employees were hired in a spot market. Job tenures were short, and foremen hired workers are determined their wages. In the early twentieth century, however, things changed. There are various explanations for why things changed. Brown and Phillips (1986) suggest that canning firms were able to wrest power from the craft unions by introducing machines that required less skill. Jacoby (1985) suggests that

\footnotetext{
${ }^{34}$ While he does not report the p-value, Leonard does claim that the gender earnings ratio is "significantly less than the productivity ratio." Leonard (1984), p. 162.

35 Goldin (1990), p. 114.
} 
firms established personnel departments and rules for hiring and wage-setting in order to forestall unionization and to deal with government regulation.

Among the many changes that occurred during this time were the adoption of job ladders and steeper wage profiles. Firms began to offer more opportunities for internal promotion, moving workers through a defined serious of jobs, and workers experienced more wage growth during their adult years. A number of different explanations have been given for these changes. Some suggest that the job ladders were not necessary for skill formation, but were more of a worker management tool. The employment of both skilled and unskilled workers fell while that of semi-skilled workers rose, and firms may have used job ladders to placate workers who had lost the independence and power that came with craft skills. ${ }^{36}$ Stone (1974) claims that "the development of hierarchy in the labor force was not a response to the increased complexity of jobs, but rather a device to counter the increased simplicity and homogeneity of jobs. ${ }^{, 37}$ She suggests that when mechanization replaced craft workers, "workers lost their stake in production, so that the problem of motivation arose." Job ladders solved this problem by giving workers "the illusion that they had a stake in production.,"38

Others have suggested that job ladders and increasing wage profiles were designed to reduce turnover. Owen (1995) suggests that technological change, specifically the automated machinery, increased the importance of firm-specific human capital. More people were hired into jobs which

required knowledge of particular machines as they were operated in the production process of a given plant; knowledge that constituted firm-specific skills... This shift in the skill composition of the work-force toward workers with more firm-specific skills should have led to an increase in the cost of labor turnover to the employer. ${ }^{39}$

Brown and Philips (1986) suggest that the problem was not so much the fact that skills were not transferable to another firm as the fact that information about skills was not transferable: "knowledge that a particular worker had completed a certain level of training was detectable only through the direct observation of his co-workers and immediate supervisor. Thus, while the

\footnotetext{
${ }^{36}$ Gordon, Edwards, and Reich (1982), p. 133; Stone (1974), p. $124 .$.

${ }^{37}$ Stone (1974), p. 114.

${ }^{38}$ Stone (1974), p. 127-8

${ }^{39}$ Owen (1995), p. 505.
} 
skills learned were industry-general, credit for attaining those skills was largely firm-specific. ${ }^{\wedge 0}$ In either case, firms had an incentive to keep their workers. Since turnover was more costly, firms introduced various incentives, including delayed compensation, to discourage workers from quitting. If firms paid workers less when first hired, but increased their wages with tenure, workers would have more incentive to stay with the firm. Firms were successful; quit rates fell from 101 per 100 employees in 1920 to 26 in $1928 .^{41}$

There is some evidence that, when internal labor market policies were in put place, women did not have the same opportunities for advancement as men. Goldin finds that, among American clerical workers "Each year of total experience augmented male earnings more than female earnings. ${ }^{42}$ Men were assigned to jobs with promotion possibilities and women were not. Similarly, Seltzer and Frank (2008) find that, among employees of a British bank in the early twentieth century, men and women were paid approximately the same salary when first hired, but after about eight years at the firm a substantial wage gap appeared. Examining Swedish workers in the 1930s, Svensson (2008) finds that women were assigned to dead-end jobs will little prospect for wage increases, while men were assigned to jobs with increasing wage profiles. Owen (2001) finds that the advent of internal labor markets in the 1920s made male, but not female, quit rates less responsive to the business cycle. She concludes that "there were gender differences in the benefits received from the development of internal labor markets. ${ }^{~} 33$ Different explanations of job ladders lead to different explanations of this gender difference. If job ladders were adopted to placate male workers and forestall unionization, then women were not offered these opportunities because they were less troublesome workers. Denying women access to the job ladders may have actually helped please the men. ${ }^{44}$ If job ladders were introduced to reduce turnover, then women may have been shut out because their quits were less responsive to economic incentives. Men and women tend to quit for different reasons; while women are more likely to quit for family reasons, men are more likely to quit for economic reasons. ${ }^{45}$ If male turnover was more sensitive to economic considerations, employers

\footnotetext{
${ }^{40}$ Brown and Philips (1986), p. 135.

41 Owen (1995), p. 499.

42 Goldin (1990), p. 108.

43 Owen (2001), p. 60.

44 Brown and Philips (1986), p. 141.

${ }^{45}$ For current labor markets, Sicherman (1996, p. 501) concludes that "on-the-job training and long-run (career) considerations were more important determinants of male mobility than of female mobility." See also Keith and
} 
may have concentrated their efforts on the group whose behavior they could more easily change. Whatever the explanation, the results was diverging wage profiles and limited opportunities for women to advance. The movement away from spot labor markets mainly benefited men.

McWilliams (1995). Hareven (1982, p. 245) finds the same thing among workers at the Amoskeag cotton mill in the 1920s; men were more likely to leave for work-related reasons, while women were more likely to leave for family reasons. 


\section{Bibliography}

Aigner, D., Lovell, C.A.K., and Schmidt, P., 1977, "Formulation and estimation of stochastic frontier production function models," Journal of Econometrics, 6:21-37.

Altonji, Joseph, and Blank, Rebecca, 1999, "Race and Gender in the Labor Market," in Ashenfelter and Card, eds., Handbook of Labor Economics, Elsevier.

Atack, Jeremy, Bateman, Fred, and Margo, Robert, 2003, "Productivity in Manufacturing and the Length of the Working Day: Evidence from the 1880 Census of Manufactures," Explorations in Economic History, 40:170-194.

Atack, Jeremy, Bateman, Fred, and Margo, Robert, 2004, "Skill Intensity and Rising Wage Dispersion in Nineteenth-Century American Manufacturing," Journal of Economic History, 64: 172-192.

Atack, Jeremy, Bateman, Fred, and Margo, Robert, 2005, "Capital deepening and the rise of the factory: the American experience during the nineteenth century," Economic History Review, 68:586-595.

Atack, Jeremy, Bateman, Fred and Weiss, Thomas, (2004), National Samples from the Census of Manufacturing, 1850, 1860, and 1870, ICPSR04048, Urbana, IL: University of Illinois, Bloomington, IN: Indiana University, Lawrence, KS: University of Kansas [producers], 2004. Ann Arbor, MI: Inter-University Consortium for Political and Social Research [distributor].

Becker, Gary, 1971, The Economics of Discrimination, $2^{\text {nd }}$ ed., Chicago: University of Chicago Press.

Becker, Gary, 1985, "Human Capital, Effort, and the Sexual Division of Labor," Journal of Labor Economics, 3: S33-S58

Bessen, James, 2003, "Technology and Learning by Factory Workers: The Stretch-Out at Lowell, 1842," Journal of Economics History, 63:33-64.

Bessen, James, 2008, "More Machines or Better Machines?" unpublished

Brown, Martin, and Philips, Peter, 1985, "The Evolution of Labor Market Structure" Industrial and Labor Relations Review, 38:392-407

, 1986, "The Historical Origin of Job Ladders in the US Canning Industry and Their Effects on the Gender Division of Labour" Cambridge Journal of Economics, 10:129-45.

Burnette, Joyce, 1996, "Testing for Occupational Crowding in Eighteenth-Century British Agriculture," Explorations in Economic History, 33:319-345. 
Carden, Art, 2004, "Unequal Pay for Unequal Work in Antebellum America," mimeo.

Cox, Donald and Nye, John Vincent, 1989, "Male-Female Wage Discrimination in NineteenthCentury France," Journal of Economic History, 49:903-920.

Craig, Lee A. and Elizabeth Field-Hendrey, 1993, "Industrialization and the Earnings Gap: Regional and Sectoral Tests of the Goldin-Sokoloff Hypothesis," Explorations in Economic History, 30:60-80.

David, Paul, 1970, "Learning By Doing and Tariff Protection: A Reconsideration of the Case of the Ante-Bellum United States Cotton Textile Industry," Journal of Economic History, 30:521601 .

Daymont, Thomas, and Andrisani, Paul, 1984, "Job Preferences, College Major, and the Gender Gap in Earnings," Journal of Human Resources, 19:408-428.

Dodd, Donald. B., 1993, Historical Statistics of the States of the United States, Westport: Greenwood Press.

Doraszelski, Ulrich, 2004, "Measuring Returns to Scale in Nineteenth-Century French Industry," Explorations in Economic History, 41:256-281.

Dublin, Thomas, 1979, Women at Work: The Transformation of Work and Community in Lowell, Massachusetts, 1826-1860, New York: Columbia Univ. Press.

Field, Elizabeth, 1985, Elasticities of Complementarity and Returns to Scale in Antebellum Cotton Agriculture, Ph.D. diss., Duke University.

Field-Hendrey, Elizabeth, 1998, "The Role of Gender in Biased Technical Change: US Manufacturing, 1850-1919," Journal of Economic History, 58:1090-1109.

Gitelman, Howard M, 1967, “The Waltham System and the Coming of the Irish," Labor History, 8:227-253.

Goldin, Claudia, 1990, Understanding the Gender Gap: An Economic History of American Women, Oxford: Oxford Univ. Press.

Goldin, Claudia, and Rouse, Cecilia, 2000, "Orchestrating Impartiality: The Impact of 'Blind' Auditions on Female Musicians," American Economic Review, 90:715-742.

Goldin, Claudia, and Sokoloff, Kenneth, 1982, "Women, Children, and Industrialization in the Early Republic: Evidence from the Manufacturing Censuses," Journal of Economic History, 42:741-774.

Goldsmith, Veum, and Darity, 1997, "The Impact of Psychological and Human Capital on Wages," Economic Inquiry, 35:815-829. 
Gordon, David, Edwards. Richard, and Reich, Michael, 1982, Segmented Work, Divided Workers: The Historical Transformation of Labor in the United States, New York: Cambridge Univ. Press.

Haegeland, Torbjorn, and Klette, Tor Jakob, 1999, "Do Higher Wages Reflect Higher Productivity? Education, Gender and Experience Premiums in a Matched Plant-Worker Data Set" in Haltwanger, Lane, Spletzer, Theeuwes, and Troske, eds., The Creation and Analysis of Employer-Employee Matched Data, Amsterdam: Elsevier, pp. 231-259.

Harley, C. Knick, 1992, "International Competitiveness of the Antebellum American Cotton Textile Industry,” Journal of Economic History, 52:559-584.

Hareven, Tamara K., 1982, Family Time and Industrial Time: The Relationship Between the Family and Work in a New England Industrial Community, Cambridge Univ. Press.

Hellerstein, Judith, and Neumark, David, 1995, "Are Earnings Profiles Steeper Than Productivity Profiles? Evidence from Israeli Firm-Level Data," Journal of Human Resources, 30:89-112.

, 1999, "Sex, Wages, and Productivity: An Empirical Analysis of Israeli Firm-Level Data," International Economic Review, 40:95-123.

Hellerstein, Judith, Neumark, David, and Troske, Kenneth, 1999, "Wages, Productivity, and Worker Characteristics: Evidence from Plant-Level Production Functions and Wage Equations," Journal of Labor Economics, 17:409-446.

380 . , 2002, "Market Forces and Sex Discrimination," Journal of Human Resources, 37: 353-

Jacobsen, Joyce, 1994, The Economics of Gender, Cambridge, MA: Blackwell.

Jacoby, Sanford, 1985, Employing Bureaucracy: Managers, Unions, and the Transformation of Work in American Industry, 1900-1945, New York, Columbia Univ. Press

Jarrell, Stephe, and Stanley, T.D., 2004, "Declining Bias and Gender Wage Discrimination? A Meta-Regression Analysis," Journal of Human Resources, 39:828-838.

Keith, Kristen, and McWilliams, Abagail, 1995, “The Wage Effects of Cumulative Job Mobility," Industrial and Labor Relations Review, 49:121-137.

Layer, Robert George, 1952, Wages, Earnings, and Output in Four Cotton Textile Companies in New England, 1825-1860, Ph.D diss., Harvard University.

Lazonick, William, and Brush, Thomas, 1985, "The 'Horndal Effect' in Early US Manufacturing," Explorations in Economic History, 22:53-96. 
Leonard, Jonathan, 1984, "Antidiscrimination or Reverse Discrimination: The Impact of Changing Demographics, Title VII, and Affirmative Action on Productivity," Journal of Human Resources, 19:145-174.

McDevitt, Catherine, Irwin, James, and Inwood, Kris, 2009, "Gender Pay Gap, Productivity Gap and Discrimination in Canadian Clothing Manufacturing in 1870," Eastern Economic Journal, 35:24-36.

McGouldrick, Paul, and Tannen, Michael, 1980, "The Increasing Pay Gap for Women in the Textile and Clothing Industries, 1910 to 1970," Journal of Economic History, 40:799-814.

McLane, Louis, 1969 [1833], Documents Relative to the Manufactures in the United States, New York: Augustus Kelley.

Neumark, David, 1988, "Employers' Discriminatory Behavior and the Estimation of Wage Discrimination," Journal of Human Resources, 23:279-295.

Neumark, David, Roy Bank, and Kyle Van Nort, 1996, "Sex Discrimination in Restaurant Hiring: An Audit Study," Quarterly Journal of Economics, 111:915-941.

Niemi, Albert, 1982, "The Increasing Pay Gap for Women in Textile and Clothing Industries: A Reexamination," Journal of Economic History, 42:423-426

Nickless, Pamela, 1976, "Changing Labor Productivity and the Utilization of Native Women Workers in the American Cotton Textile Industry, 1825-1860," PhD diss., Purdue University.

Owen, Laura, 1995, "'Worker Turnover in the 1920s: The Role of Changing Employment Policies," Industrial and Corporate Change, 4:499_

, 2001, " "Gender Differences in Labor Turnover and the Development of Internal Labor Markets in the United States during the 1920s," Enterprise \& Society, 2:41-71.

Robinson, Harriet, 1976, Loom and Spindle or Life Among the Early Mill Girls, Kailua: Press Pacifica.

Rosenbloom, Joshua, 1990, "One Market or Many? Labor Market Integration in the Late Nineteenth-Century United States,” Journal of Economic History, 50:85-107.

Rosenbloom, Joshua L., and Sundstrom, William A., 2009, "Labor-Market Regimes in US Economic History," NBER Working Paper No. 15055

Seltzer, Andrew, and Frank, Jeff, 2008, "Female Salaries and Careers in the British Banking Industry, 1915-41," presented at the Sixth World Congress of Cliometrics, Edinburgh, July 17, 2008. 
Sicherman, Nachum, 1996, "Gender Differences in Departures from Large Firms,” Industrial and Labor Relations Review, 49:484-505.

Sokoloff, Kenneth, 1986, "Productivity Growth in Manufacturing during Early Industrialization: Evidence from the American Northeast, 1820-1860," in Stanley Engerman and Robert Gallman, eds., Long-Term Factors in American Economic Growth, Chicago: University of Chicago Press, pp. 679-729.

Stone, Katherine, 1974, "The Origins of Job Structures in the Steel Industry," Review of Radical Political Economy, Vol. 6 no 2:113-

Svensson, Lars, 2008, "Pay Differentials and Gender Based Promotion Discrimination in a Dual Labour Market: Office Work in Sweden in the mid-1930s," presented at the European Social Science History Conference, Lisbon, March 1, 2008.

Thornton, Robert, and Hyclak, Thomas, 1982, "The Increasing Pay Gap for Women in the Textile and Clothing Industries, 1910 to 1970: An Alternative Explanation," Journal of Economic History, 42:427-431.

Vedder, Richard K. , Gallaway, Lowell E., and Klingaman, David, 1978, "Discrimination and Exploitation in Antebellum American Cotton Textile Manufacturing," Research in Economic History, 3:217-262.

Williamson, Jeffrey, 1986, "Comment", in Engerman and Gallman, eds., Long-Term Factors in American Economic Growth, Univ. of Chicago Press, pp. 729-733.

Wright, Carroll, History of Wages and Prices in Massachusetts: 1752-1883, Boston: Wright and Potter, 1885

Wright, Gavin, 1986, Old South, New South: Revolutions in the Southern Economy Since the Civil War, Baton Rouge: Louisiana State University Press. 
Table 1: A Summary of Studies of Female-Male Productivity Differences

\begin{tabular}{|c|c|c|c|}
\hline$\underline{\text { Study }}$ & Location & $\begin{array}{c}\text { Wage } P \\
\text { Ratio }\end{array}$ & $\begin{array}{l}\text { oductivity } \\
\text { Ratio }\end{array}$ \\
\hline Vedder, Gallaway, and & US Cotton Textiles, 1833 & 0.40 & 0.16 \\
\hline Klingaman (1978) & 1860 & 0.56 & $1.10 \#$ \\
\hline \multirow[t]{8}{*}{ Cox and Nye (1989) } & French mfrg, 1849-45 & & \\
\hline & Cotton spinning & 0.54 & 0.63 \\
\hline & Wool spinning & 0.49 & 0.43 \\
\hline & Cotton weaving & 0.60 & 0.59 \\
\hline & Wool weaving & 0.48 & 0.37 \\
\hline & French mfrg, 1860-65 & & \\
\hline & Cotton & 0.52 & 0.72 \\
\hline & Wool & 0.50 & 1.11 \\
\hline \multirow{9}{*}{$\begin{array}{l}\text { Craig and Field-Hendrey } \\
\text { (1993) }\end{array}$} & US, 1860 & & \\
\hline & Northern Agriculture & & \\
\hline & Teenagers & 0.94 & \\
\hline & Age 19-54 & 0.61 & \\
\hline & Southern Agriculture & & \\
\hline & Free labor, age 19-54 & 0.72 & \\
\hline & Slaves, age 20-54 & 0.60 & \\
\hline & Northern Manufacturing & 0.50 & \\
\hline & Southern Manufacturing & 0.44 & \\
\hline $\begin{array}{l}\text { McDevitt, Irwin, and Inwood } \\
\text { (2009) }\end{array}$ & Canadian manufacturing, 1870 & 0.38 & $0.49^{*}$ \\
\hline \multirow[t]{2}{*}{ Leonard (1984) } & US manufacturing, 1966 & 0.53 & $0.75^{*}$ \\
\hline & 1977 & 0.54 & $1.01^{*}$ \\
\hline Haegeland and Klette (1999) & Norwegian mfrg., 1986-93 & 0.82 & 0.83 \\
\hline Hellerstein and Neumark (1999) & Israeli mfrg., 1989 & 0.77 & 0.82 \\
\hline $\begin{array}{l}\text { Hellerstein, Neumark, Troske } \\
\text { (1999) }\end{array}$ & US 1990 & 0.55 & $0.84^{*}$ \\
\hline
\end{tabular}


Table 2: Descriptive Statistics, McLane Report, Massachusetts 1833

\section{A. Singles}

\begin{tabular}{lrrrrr} 
& Mean & Std.Dev. & Min & Max & N \\
\hline Output (\$) & 23,463 & 49,590 & 300 & 500,000 & 737 \\
Materials (\$) & 12,582 & 29,661 & 48 & 367,300 & 737 \\
Capital (\$) & 20,260 & 61,552 & 120 & 920,086 & 737 \\
Men & 12.5 & 20.3 & 0 & 200 & 737 \\
Females & 15.6 & 47.2 & 0 & 672 & 737 \\
Boys & 2.9 & 8.3 & 0 & 141 & 737 \\
Men's Wage (\$) & 0.97 & 0.24 & 0.33 & 2.25 & 715 \\
Female Wage (\$) & 0.37 & 0.13 & 0.02 & 1.20 & 369 \\
Boys' Wage (\$) & 0.40 & 0.14 & 0.11 & 1.00 & 259 \\
\hline
\end{tabular}

\section{B. Full Sample}

\begin{tabular}{lrrrrr} 
& Mean & Std.Dev. & Min & Max & $\mathrm{N}$ \\
\hline Output (\$) & 34,094 & 136,770 & 180 & $4,180,000$ & 1391 \\
Materials (\$) & 17,325 & 55,329 & 13 & $1,190,000$ & 1391 \\
Capital (\$) & 20,965 & 58,082 & 100 & 920,086 & 1391 \\
Men & 19.3 & 44.3 & 0 & 562 & 1391 \\
Females & 15.9 & 52.2 & 0 & 672 & 1391 \\
Boys & 3.7 & 12.6 & 0 & 200 & 1391 \\
Men's Wage (\$) & 1.00 & 0.26 & 0.33 & 3.5 & 1340 \\
Female Wage (\$) & 0.38 & 0.12 & 0.02 & 1.2 & 553 \\
Boys' Wage (\$) & 0.43 & 0.14 & 0.11 & 1.0 & 464 \\
\hline
\end{tabular}

\section{Textiles}

\begin{tabular}{lrrrrr} 
& Mean & Std.Dev. & Min & Max & $\mathrm{N}$ \\
\hline Output (\$) & 49,117 & 95,666 & 240 & 900,000 & 426 \\
Materials (\$) & 26,246 & 58,439 & 30 & 720,530 & 426 \\
Capital (\$) & 70,547 & 258,129 & 250 & $4,200,000$ & 426 \\
Men & 18.6 & 34.6 & 0 & 312 & 426 \\
Females & 49.7 & 110.7 & 0 & 1050 & 426 \\
Boys & 8.2 & 18.1 & 0 & 141 & 426 \\
Men's Wage (\$) & 0.96 & 0.31 & 0.17 & 5.0 & 413 \\
Female Wage (\$) & 0.39 & 0.08 & 0.11 & 0.83 & 383 \\
Boys' Wage (\$) & 0.33 & 0.12 & 0.11 & 0.98 & 242 \\
\hline
\end{tabular}

D. Boots and Shoes

\begin{tabular}{lrrrrr} 
& Mean & Std.Dev. & Min & Max & N \\
\hline Output (\$) & 22,019 & 57,990 & 25 & 508,000 & 319 \\
Materials (\$) & 10,925 & 29,609 & 15 & 281,370 & 319 \\
Capital (\$) & 5533 & 29,569 & 18 & 510,000 & 319 \\
Men & 29.4 & 68.9 & 0 & 562 & 319 \\
Females & 15.6 & 36.4 & 0 & 300 & 319 \\
Boys & 6.3 & 20.6 & 0 & 200 & 319 \\
Men's Wage (\$) & 0.79 & 0.19 & 0.33 & 2.80 & 295 \\
Female Wage (\$) & 0.26 & 0.11 & 0.02 & 0.60 & 146 \\
Boys' Wage (\$) & 0.39 & 0.14 & 0.11 & 1.00 & 94 \\
\hline
\end{tabular}


Table 3: Production Functions for Massachusetts, 1833

\begin{tabular}{|c|c|c|c|c|c|c|}
\hline Parameter & Singles & $\begin{array}{c}\text { Add } \\
\text { Entrepreneur } \\
\end{array}$ & $\begin{array}{l}\text { Full } \\
\text { Sample } \\
\end{array}$ & Textiles & $\begin{array}{l}\text { Boots and } \\
\text { Shoes }\end{array}$ & $\begin{array}{r}\text { Combine } \\
\text { Males } \\
\end{array}$ \\
\hline Constant & $\begin{array}{c}4.077 \\
(0.447)\end{array}$ & $\begin{array}{c}3.524 \\
(0.403)\end{array}$ & $\begin{array}{c}4.467 \\
(0.255)\end{array}$ & $\begin{array}{l}3.662 \\
(1.456)\end{array}$ & $\begin{array}{c}3.334 \\
(1.078)\end{array}$ & $\begin{array}{c}3.975 \\
(0.443)\end{array}$ \\
\hline $\mathrm{a}_{\mathrm{K}}$ & $\begin{array}{c}0.362 \\
(0.100)\end{array}$ & $\begin{array}{c}0.317 \\
(0.097)\end{array}$ & $\begin{array}{c}0.206 \\
(0.069)\end{array}$ & $\begin{array}{c}0.914 \\
(0.321)\end{array}$ & $\begin{array}{c}0.365 \\
(0.263)\end{array}$ & $\begin{array}{c}0.362 \\
(0.100)\end{array}$ \\
\hline$a_{R M}$ & $\begin{array}{c}-0.149 \\
(0.105)\end{array}$ & $\begin{array}{c}-0.061 \\
(0.100)\end{array}$ & $\begin{array}{c}-0.153 \\
(0.055)\end{array}$ & $\begin{array}{c}-0.574 \\
(0.255)\end{array}$ & $\begin{array}{c}-0.085 \\
(0.413)\end{array}$ & $\begin{array}{c}-0.129 \\
(0.106)\end{array}$ \\
\hline$a_{L}$ & $\begin{array}{c}0.814 \\
(0.143)\end{array}$ & $\begin{array}{c}1.024 \\
(0.158)\end{array}$ & $\begin{array}{c}0.995 \\
(0.071)\end{array}$ & $\begin{array}{c}0.481 \\
(0.457)\end{array}$ & $\begin{array}{c}0.941 \\
(0.482)\end{array}$ & $\begin{array}{c}0.774 \\
(0.141)\end{array}$ \\
\hline $\mathrm{a}_{\mathrm{KK}}$ & $\begin{array}{c}0.021 \\
(0.009)\end{array}$ & $\begin{array}{c}0.018 \\
(0.010)\end{array}$ & $\begin{array}{c}0.037 \\
(0.007)\end{array}$ & $\begin{array}{c}-0.012 \\
(0.025)\end{array}$ & $\begin{array}{c}0.016 \\
(0.020)\end{array}$ & $\begin{array}{c}0.024 \\
(0.010)\end{array}$ \\
\hline $\mathrm{a}_{\text {RMRM }}$ & $\begin{array}{c}0.101 \\
(0.009)\end{array}$ & $\begin{array}{c}0.097 \\
(0.009)\end{array}$ & $\begin{array}{c}0.102 \\
(0.005)\end{array}$ & $\begin{array}{c}0.133 \\
(0.014)\end{array}$ & $\begin{array}{c}0.120 \\
(0.046)\end{array}$ & $\begin{array}{c}0.103 \\
(0.009)\end{array}$ \\
\hline$a_{L L}$ & $\begin{array}{c}0.032 \\
(0.014)\end{array}$ & $\begin{array}{c}0.010 \\
(0.023)\end{array}$ & $\begin{array}{c}0.051 \\
(0.007)\end{array}$ & $\begin{array}{l}-0.011 \\
(0.045)\end{array}$ & $\begin{array}{c}0.068 \\
(0.056)\end{array}$ & $\begin{array}{c}0.031 \\
(0.014)\end{array}$ \\
\hline $\mathrm{a}_{\mathrm{KRM}}$ & $\begin{array}{l}-0.083 \\
(0.017)\end{array}$ & $\begin{array}{c}-0.077 \\
(0.017)\end{array}$ & $\begin{array}{c}-0.086 \\
(0.010)\end{array}$ & $\begin{array}{l}-0.095 \\
(0.035)\end{array}$ & $\begin{array}{c}-0.094 \\
(0.043)\end{array}$ & $\begin{array}{c}-0.088 \\
(0.017)\end{array}$ \\
\hline$a_{\mathrm{KL}}$ & $\begin{array}{c}0.050 \\
(0.016)\end{array}$ & $\begin{array}{c}0.068 \\
(0.019)\end{array}$ & $\begin{array}{c}0.012 \\
(0.010)\end{array}$ & $\begin{array}{c}0.113 \\
(0.051)\end{array}$ & $\begin{array}{c}0.079 \\
(0.053)\end{array}$ & $\begin{array}{c}0.049 \\
(0.016)\end{array}$ \\
\hline $\mathrm{a}_{\mathrm{RML}}$ & $\begin{array}{c}-0.128 \\
(0.021)\end{array}$ & $\begin{array}{l}-0.152 \\
(0.025)\end{array}$ & $\begin{array}{l}-0.121 \\
(0.010)\end{array}$ & $\begin{array}{c}-0.133 \\
(0.068)\end{array}$ & $\begin{array}{l}-0.195 \\
(0.089)\end{array}$ & $\begin{array}{c}-0.124 \\
(0.021)\end{array}$ \\
\hline$b_{1}$ & $\begin{array}{c}0.365 \\
(0.064)\end{array}$ & $\begin{array}{c}0.344 \\
(0.062)\end{array}$ & $\begin{array}{c}0.454 \\
(0.046)\end{array}$ & $\begin{array}{c}0.380 \\
(0.068)\end{array}$ & $\begin{array}{c}0.266 \\
(0.192)\end{array}$ & $\begin{array}{c}0.354 \\
(0.071)\end{array}$ \\
\hline$b_{2}$ & $\begin{array}{c}0.392 \\
(0.117)\end{array}$ & $\begin{array}{c}0.395 \\
(0.119)\end{array}$ & $\begin{array}{c}0.420 \\
(0.106)\end{array}$ & $\begin{array}{c}0.377 \\
(0.132)\end{array}$ & $\begin{array}{c}0.519 \\
(0.239)\end{array}$ & \\
\hline $\begin{array}{l}\text { Female/Men } \\
\text { Wage Ratio } \\
\text { p-value }\end{array}$ & $\begin{array}{l}0.41 \\
0.76\end{array}$ & $\begin{array}{l}0.41 \\
0.86\end{array}$ & $\begin{array}{l}0.41 \\
0.17\end{array}$ & $\begin{array}{l}0.43 \\
0.77\end{array}$ & $\begin{array}{l}0.34 \\
0.65\end{array}$ & $\begin{array}{l}0.47 \\
0.95\end{array}$ \\
\hline $\begin{array}{l}\text { Boys/Men } \\
\text { Wage Ratio } \\
\text { p-value }\end{array}$ & $\begin{array}{l}0.43 \\
0.63\end{array}$ & $\begin{array}{l}0.43 \\
0.62\end{array}$ & $\begin{array}{l}0.43 \\
0.54\end{array}$ & $\begin{array}{l}0.35 \\
0.42\end{array}$ & $\begin{array}{l}0.51 \\
0.48\end{array}$ & \\
\hline $\begin{array}{l}\mathrm{R}^{2} \\
\mathrm{~N}\end{array}$ & $\begin{array}{r}0.96 \\
737 \\
\end{array}$ & $\begin{array}{r}0.96 \\
737 \\
\end{array}$ & $\begin{array}{r}0.97 \\
1391 \\
\end{array}$ & $\begin{array}{r}0.96 \\
426\end{array}$ & $\begin{array}{r}0.97 \\
319 \\
\end{array}$ & $\begin{array}{r}0.96 \\
737 \\
\end{array}$ \\
\hline
\end{tabular}

"p-value" is the $p$-value for a one-tail test of the null hypothesis $b \geq$ wage ratio. Wage discrimination occurs if $b>$ wage ratio, so rejection of the null is evidence of discrimination.

Wage ratio for the "combine males" column is the average female wage divided by a weighted average of the men's and boys' wages. 
Table 4: Descriptive Statistics, Census of Manufactures, 1850 and 1860

\begin{tabular}{|c|c|c|c|c|c|}
\hline & Mean & Std.Dev. & Min & Max & $\mathrm{N}$ \\
\hline \multicolumn{6}{|l|}{1850} \\
\hline Output (\$) & 12,594 & 40,254 & 200 & $1,025,000$ & 1971 \\
\hline Materials (\$) & 6955 & 24,578 & 37 & 569,740 & 1971 \\
\hline Capital (\$) & 7390 & 39,415 & 10 & $1,200,000$ & 1971 \\
\hline Men & 8.97 & 25.23 & 0 & 500 & 1971 \\
\hline Women & 5.83 & 45.87 & 0 & 1600 & 1971 \\
\hline Male Monthly Wage & 24.39 & 10.59 & 0.04 & 317 & 1957 \\
\hline Female Monthly Wage & 10.94 & 6.18 & 0.8 & 108 & 532 \\
\hline Wage Ratio (F/M) & 0.482 & 0.345 & 0.04 & 5.4 & 521 \\
\hline \multicolumn{6}{|l|}{1860} \\
\hline Output (\$) & 22,990 & 73,599 & 150 & $1,680,000$ & 1816 \\
\hline Materials (\$) & 12,145 & 41,828 & 10 & 905,100 & 1816 \\
\hline Capital (\$) & 12,195 & 59,383 & 15 & $1,500,000$ & 1816 \\
\hline Men & 11.69 & 32.09 & 0 & 500 & 1816 \\
\hline Women & 7.50 & 60.24 & 0 & 1760 & 1816 \\
\hline Male Monthly Wage & 27.70 & 12.10 & 1 & 351 & 1788 \\
\hline Female Monthly Wage & 12.88 & 8.11 & 0.7 & 150 & 494 \\
\hline Wage Ratio (F/M) & 0.525 & 0.449 & 0.03 & 6.1 & 476 \\
\hline \multicolumn{6}{|l|}{1850 Textiles } \\
\hline Output (\$) & 33,323 & 82,661 & 400 & $1,025,000$ & 235 \\
\hline Materials (\$) & 20,247 & 50,434 & 120 & 569,740 & 235 \\
\hline Capital (\$) & 30,996 & 98,935 & 150 & $1,200,000$ & 235 \\
\hline Men & 17.7 & 34.2 & 0 & 320 & 235 \\
\hline Women & 23.5 & 72.5 & 0 & 870 & 235 \\
\hline Male Monthly Wage & 19.42 & 7.64 & 1.75 & 66.67 & 234 \\
\hline Female Monthly Wage & 11.99 & 9.55 & 1 & 108 & 156 \\
\hline Wage Ratio (F/M) & 0.64 & 0.53 & 0.15 & 5.40 & 155 \\
\hline \multicolumn{6}{|l|}{1860 Textiles } \\
\hline Output (\$) & 67,463 & 161,281 & 500 & $1,680,000$ & 181 \\
\hline Materials (\$) & 38,683 & 92,195 & 210 & 905,100 & 181 \\
\hline Capital (\$) & 45.352 & 145,989 & 100 & $1,500,000$ & 181 \\
\hline Men & 24.6 & 45.7 & 0 & 400 & 181 \\
\hline Women & 41.9 & 171.0 & 0 & 1760 & 181 \\
\hline Male Monthly Wage & 22.97 & 8.89 & 1.30 & 60.00 & 177 \\
\hline Female Monthly Wage & 12.84 & 6.22 & 0.95 & 50.00 & 122 \\
\hline Wage Ratio (F/M) & 0.60 & 0.22 & 0.13 & 1.42 & 121 \\
\hline
\end{tabular}


Table 5: Production Functions for All Manufacturing, 1850 and 1860

\begin{tabular}{|c|c|c|c|c|c|c|}
\hline$\underline{\text { Parameter }}$ & 1850 & $\begin{array}{c}1850 \text { Add } \\
\text { Entrepreneur }\end{array}$ & $\begin{array}{c}1850 \\
\text { Textiles }\end{array}$ & 1860 & $\begin{array}{l}1860 \text { Add } \\
\text { Entrepreneur }\end{array}$ & $\begin{array}{l}1860 \\
\text { Textiles }\end{array}$ \\
\hline Constant & $\begin{array}{c}4.850^{*} \\
(0.276)\end{array}$ & $\begin{array}{c}4.314^{*} \\
(0.248)\end{array}$ & $\begin{array}{c}2.297 * \\
(1.115)\end{array}$ & $\begin{array}{r}5.267 * \\
(0.321)\end{array}$ & $\begin{array}{c}4.689 * \\
(0.281)\end{array}$ & $\begin{array}{r}7.355^{*} \\
(1.037)\end{array}$ \\
\hline$a_{K}$ & $\begin{array}{c}0.226^{*} \\
(0.064)\end{array}$ & $\begin{array}{c}0.198^{*} \\
(0.059)\end{array}$ & $\begin{array}{r}0.534^{*} \\
(0.234)\end{array}$ & $\begin{array}{c}0.072 \\
(0.078)\end{array}$ & $\begin{array}{c}0.038 \\
(0.072)\end{array}$ & $\begin{array}{l}-0.291 \\
(0.194)\end{array}$ \\
\hline$a_{R M}$ & $\begin{array}{r}-0.181 * \\
(0.070)\end{array}$ & $\begin{array}{c}-0.145^{*} \\
(0.066)\end{array}$ & $\begin{array}{c}0.094 \\
(0.263)\end{array}$ & $\begin{array}{r}-0.175^{*} \\
(0.067)\end{array}$ & $\begin{array}{c}-0.134^{*} \\
(0.063)\end{array}$ & $\begin{array}{r}0.498 \\
(0.259)\end{array}$ \\
\hline$a_{L}$ & $\begin{array}{c}0.777 * \\
(0.078)\end{array}$ & $\begin{array}{c}1.088^{*} \\
(0.089)\end{array}$ & $\begin{array}{c}0.506 \\
(0.350)\end{array}$ & $\begin{array}{c}0.959 * \\
(0.092)\end{array}$ & $\begin{array}{c}1.288^{*} \\
(0.101)\end{array}$ & $\begin{array}{l}1.521^{*} \\
(0.240)\end{array}$ \\
\hline$a_{\mathrm{KK}}$ & $\begin{array}{c}0.011 \\
(0.006)\end{array}$ & $\begin{array}{c}0.010 \\
(0.006)\end{array}$ & $\begin{array}{c}0.012 \\
(0.023)\end{array}$ & $\begin{array}{c}0.041 * \\
(0.007)\end{array}$ & $\begin{array}{c}0.040 * \\
(0.007)\end{array}$ & $\begin{array}{r}0.012 \\
(0.018)\end{array}$ \\
\hline$a_{\text {RMRM }}$ & $\begin{array}{c}0.081 * \\
(0.007)\end{array}$ & $\begin{array}{r}0.084 * \\
(0.007)\end{array}$ & $\begin{array}{c}0.098^{*} \\
(0.021)\end{array}$ & $\begin{array}{c}0.100 * \\
(0.006)\end{array}$ & $\begin{array}{c}0.101 * \\
(0.006)\end{array}$ & $\begin{array}{l}0.078 * \\
(0.021)\end{array}$ \\
\hline$a_{L L}$ & $\begin{array}{c}-0.002 \\
(0.009)\end{array}$ & $\begin{array}{c}-0.021 \\
(0.012)\end{array}$ & $\begin{array}{c}0.006 \\
(0.035)\end{array}$ & $\begin{array}{c}0.014 \\
(0.009)\end{array}$ & $\begin{array}{c}0.005 \\
(0.012)\end{array}$ & $\begin{array}{c}0.065^{*} \\
(0.020)\end{array}$ \\
\hline $\mathrm{a}_{\mathrm{KRM}}$ & $\begin{array}{c}-0.046^{*} \\
(0.011)\end{array}$ & $\begin{array}{c}-0.046^{*} \\
(0.011)\end{array}$ & $\begin{array}{r}-0.097 * \\
(0.039)\end{array}$ & $\begin{array}{r}-0.082 * \\
(0.011)\end{array}$ & $\begin{array}{c}-0.079 * \\
(0.011)\end{array}$ & $\begin{array}{r}0.023 \\
(0.035)\end{array}$ \\
\hline $\mathrm{a}_{\mathrm{KL}}$ & $\begin{array}{c}0.036^{*} \\
(0.012)\end{array}$ & $\begin{array}{c}0.048^{*} \\
(0.015)\end{array}$ & $\begin{array}{c}0.085 * \\
(0.041)\end{array}$ & $\begin{array}{c}0.025 \\
(0.013)\end{array}$ & $\begin{array}{c}0.030^{*} \\
(0.015)\end{array}$ & $\begin{array}{l}-0.007 \\
(0.043)\end{array}$ \\
\hline$a_{\mathrm{RML}}$ & $\begin{array}{c}-0.091 * \\
(0.012)\end{array}$ & $\begin{array}{c}-0.120 * \\
(0.015)\end{array}$ & $\begin{array}{c}-0.119 * \\
(0.043)\end{array}$ & $\begin{array}{c}-0.108 * \\
(0.011)\end{array}$ & $\begin{array}{c}-0.138 * \\
(0.013)\end{array}$ & $\begin{array}{r}-0.161 * \\
(0.038)\end{array}$ \\
\hline$b_{1}$ & $\begin{array}{c}0.557^{*} \\
(0.087)\end{array}$ & $\begin{array}{c}0.538 * \\
(0.082)\end{array}$ & $\begin{array}{c}0.498 * \\
(0.194)\end{array}$ & $\begin{array}{c}0.666^{*} \\
(0.094)\end{array}$ & $\begin{array}{c}0.636^{*} \\
(0.090)\end{array}$ & $\begin{array}{c}0.903 * \\
(0.241)\end{array}$ \\
\hline $\begin{array}{l}\text { Female/Men } \\
\text { Wage Ratio } \\
\text { p-value }\end{array}$ & $\begin{array}{l}0.48 \\
0.19\end{array}$ & $\begin{array}{l}0.48 \\
0.24\end{array}$ & $\begin{array}{l}0.64 \\
0.77\end{array}$ & $\begin{array}{l}0.53 \\
0.07\end{array}$ & $\begin{array}{l}0.53 \\
0.12\end{array}$ & $\begin{array}{l}0.60 \\
0.10\end{array}$ \\
\hline $\begin{array}{l}\mathrm{R}^{2} \\
\mathrm{~N}\end{array}$ & $\begin{array}{r}0.93 \\
1971 \\
\end{array}$ & $\begin{array}{r}0.93 \\
1971 \\
\end{array}$ & $\begin{array}{r}0.97 \\
235 \\
\end{array}$ & $\begin{array}{r}0.93 \\
1816 \\
\end{array}$ & $\begin{array}{r}0.93 \\
1816 \\
\end{array}$ & $\begin{array}{r}0.97 \\
181 \\
\end{array}$ \\
\hline
\end{tabular}


Table 6: Descriptive Statistics, Census of Manufactures, 1870 and 1880

Mean Std.Dev. $\quad$ Min $\quad$ Max $\quad$ N

\begin{tabular}{|c|c|c|c|c|c|}
\hline \multicolumn{6}{|l|}{1870} \\
\hline Capital (\$) & 21,577 & 118,770 & 10 & $3,000,000$ & 1177 \\
\hline Output (\$) & 39,508 & 188,122 & 250 & $4,532,422$ & 1177 \\
\hline Materials (\$) & 21,682 & 119,613 & 25 & $3,050,937$ & 1177 \\
\hline Percent of the Year & 0.85 & 0.24 & 0.08 & 1.00 & 1177 \\
\hline Adjusted Output (\$) & 43,063 & 195,793 & 250 & $4,532,422$ & 1177 \\
\hline Adjusted Materials (\$) & 23,702 & 123,009 & 25 & $3,050,937$ & 1177 \\
\hline Men & 14.02 & 78.42 & 0 & 2267 & 1177 \\
\hline Women & 5.31 & 33.88 & 0 & 600 & 1177 \\
\hline Children & 2.96 & 37.05 & 0 & 1200 & 1177 \\
\hline Wage Bill & 8929 & 39,824 & 1 & 936,473 & 1005 \\
\hline \multicolumn{6}{|l|}{1880} \\
\hline Capital (\$) & 12,843 & 173,569 & 10 & $11,000,000$ & 4269 \\
\hline Output (\$) & 24,415 & 139,799 & 100 & $6,000,000$ & 4269 \\
\hline Materials (\$) & 15,548 & 114,354 & 10 & $5,600,000$ & 4269 \\
\hline Percent of Year & 0.86 & 0.22 & 0.08 & 1.00 & 4269 \\
\hline Adjusted Output (\$) & 27,358 & 145,989 & 104 & $6,000,000$ & 4269 \\
\hline Adjusted Materials (\$) & 17,269 & 117,429 & 10 & $5,600,000$ & 4269 \\
\hline Men & 9.67 & 42.49 & 0 & 1544 & 4269 \\
\hline Women & 3.49 & 43.57 & 0 & 2400 & 4269 \\
\hline Children & 0.67 & 8.77 & 0 & 500 & 4269 \\
\hline Men, adjusted & 9.73 & 42.84 & 0 & 1544 & 4269 \\
\hline Women, adjusted & 3.48 & 43.68 & 0 & 2400 & 4269 \\
\hline Children, adjusted & 0.67 & 8.82 & 0 & 500 & 4269 \\
\hline Wage Bill & 4475 & 16,925 & 5 & 422,530 & 4070 \\
\hline
\end{tabular}

Output and Raw Materials are adjusted to a full year. Adjusted output $=$ output/percent of the year worked.

Employment figures are adjusted to a ten-hour day. Adjusted men $=$ men*(hours/10) 
Table 7: Production Functions for All Manufacturing, 1870 and 1880

\begin{tabular}{|c|c|c|c|c|}
\hline$\underline{\text { Parameter }}$ & 1870 & $\begin{array}{l}1870 \text { Add } \\
\text { Entrepreneur }\end{array}$ & 1880 & $\begin{array}{c}1880 \text { Add } \\
\text { Entrepreneur }\end{array}$ \\
\hline Constant & $\begin{array}{c}5.149 * \\
(0.299)\end{array}$ & $\begin{array}{c}4.439 * \\
(0.260)\end{array}$ & $\begin{array}{c}5.187^{*} \\
(0.165)\end{array}$ & $\begin{array}{c}4.628^{*} \\
(0.140)\end{array}$ \\
\hline$a_{K}$ & $\begin{array}{c}0.143 * \\
(0.067)\end{array}$ & $\begin{array}{c}0.129 * \\
(0.062)\end{array}$ & $\begin{array}{c}0.059 \\
(0.040)\end{array}$ & $\begin{array}{c}0.037 \\
(0.037)\end{array}$ \\
\hline$a_{\mathrm{RM}}$ & $\begin{array}{c}-0.093 \\
(0.068)\end{array}$ & $\begin{array}{c}-0.028 \\
(0.063)\end{array}$ & $\begin{array}{c}-0.039 \\
(0.036)\end{array}$ & $\begin{array}{c}0.008 * \\
(0.034)\end{array}$ \\
\hline$a_{L}$ & $\begin{array}{c}0.894^{*} \\
(0.096)\end{array}$ & $\begin{array}{c}1.179 * \\
(0.110)\end{array}$ & $\begin{array}{c}0.810^{*} \\
(0.053)\end{array}$ & $\begin{array}{c}1.082 * \\
(0.060)\end{array}$ \\
\hline $\mathrm{a}_{\mathrm{KK}}$ & $\begin{array}{c}0.016 * \\
(0.006)\end{array}$ & $\begin{array}{c}0.017 * \\
(0.006)\end{array}$ & $\begin{array}{c}0.018^{*} \\
(0.003)\end{array}$ & $\begin{array}{c}0.017 * \\
(0.003)\end{array}$ \\
\hline $\mathrm{a}_{\mathrm{RMRM}}$ & $\begin{array}{c}0.071 * \\
(0.006)\end{array}$ & $\begin{array}{c}0.072 * \\
(0.006)\end{array}$ & $\begin{array}{c}0.067^{*} \\
(0.003)\end{array}$ & $\begin{array}{c}0.069 * \\
(0.003)\end{array}$ \\
\hline$a_{L L}$ & $\begin{array}{c}0.033 * \\
(0.012)\end{array}$ & $\begin{array}{c}0.038^{*} \\
(0.017)\end{array}$ & $\begin{array}{c}0.040 * \\
(0.006)\end{array}$ & $\begin{array}{c}0.041 * \\
(0.008)\end{array}$ \\
\hline $\mathrm{a}_{\mathrm{KRM}}$ & $\begin{array}{c}-0.044^{*} \\
(0.009)\end{array}$ & $\begin{array}{c}-0.043 * \\
(0.009)\end{array}$ & $\begin{array}{c}-0.037 * \\
(0.005)\end{array}$ & $\begin{array}{c}-0.036 * \\
(0.005)\end{array}$ \\
\hline$a_{K L}$ & $\begin{array}{c}0.016 \\
(0.013)\end{array}$ & $\begin{array}{c}0.015 \\
(0.016)\end{array}$ & $\begin{array}{c}0.017^{*} \\
(0.007)\end{array}$ & $\begin{array}{c}0.022^{*} \\
(0.009)\end{array}$ \\
\hline $\mathrm{a}_{\mathrm{RML}}$ & $\begin{array}{c}-0.095^{*} \\
(0.012)\end{array}$ & $\begin{array}{c}-0.121^{*} \\
(0.015)\end{array}$ & $\begin{array}{c}-0.096 * \\
(0.006)\end{array}$ & $\begin{array}{c}-0.126^{*} \\
(0.008)\end{array}$ \\
\hline$b_{1}$ & $\begin{array}{c}0.582^{*} \\
(0.123)\end{array}$ & $\begin{array}{c}0.572 * \\
(0.122)\end{array}$ & $\begin{array}{c}0.696 * \\
(0.072)\end{array}$ & $\begin{array}{c}0.648^{*} \\
(0.068)\end{array}$ \\
\hline$b_{2}$ & $\begin{array}{c}-0.006 \\
(0.015)\end{array}$ & $\begin{array}{c}-0.007 \\
(0.015)\end{array}$ & $\begin{array}{c}0.798^{*} \\
(0.148)\end{array}$ & $\begin{array}{c}0.666^{*} \\
(0.146)\end{array}$ \\
\hline $\begin{array}{l}\mathrm{R}^{2} \\
\mathrm{~N}\end{array}$ & $\begin{array}{r}0.95 \\
1177\end{array}$ & $\begin{array}{r}0.95 \\
1177\end{array}$ & $\begin{array}{r}0.94 \\
4237\end{array}$ & $\begin{array}{c}0.95 \\
4237\end{array}$ \\
\hline
\end{tabular}


Table 8: Joint Estimation of Production Functions and Wage Equations, 1870 and 1880

\begin{tabular}{|c|c|c|}
\hline & 1870 & 1880 \\
\hline \multicolumn{3}{|l|}{ Production Function } \\
\hline$b_{1}$ & $\begin{array}{c}0.597 \\
(0.137)\end{array}$ & $\begin{array}{c}0.658 \\
(0.066)\end{array}$ \\
\hline $\mathrm{b}_{2}$ & $\begin{array}{c}-0.007 \\
(0.015)\end{array}$ & $\begin{array}{c}0.723 \\
(0.135)\end{array}$ \\
\hline $\mathrm{R}_{2}$ & 0.95 & 0.95 \\
\hline \multicolumn{3}{|l|}{ Wage Equation } \\
\hline Constant & $\begin{array}{c}5.699 \\
(0.030)\end{array}$ & $\begin{array}{c}5.498 \\
(0.015)\end{array}$ \\
\hline Percent Women & $\begin{array}{c}-0.093 \\
(0.149)\end{array}$ & $\begin{array}{c}-0.203 \\
(0.070)\end{array}$ \\
\hline Percent Children & $\begin{array}{r}-1.702 \\
(0.263)\end{array}$ & $\begin{array}{c}-0.649 \\
(0.140)\end{array}$ \\
\hline $\mathrm{R}_{2}$ & 0.04 & 0.008 \\
\hline \multicolumn{3}{|l|}{ Wage Ratios } \\
\hline $\mathrm{F} / \mathrm{M}$ & $\begin{array}{c}0.91 \\
(0.14)\end{array}$ & $\begin{array}{c}0.82 \\
(0.06)\end{array}$ \\
\hline $\mathrm{C} / \mathrm{M}$ & $\begin{array}{c}0.18 \\
(0.05)\end{array}$ & $\begin{array}{c}0.52 \\
(0.07)\end{array}$ \\
\hline \multicolumn{3}{|c|}{ p-value of test of equality of wage and productivity ratios } \\
\hline $\mathrm{F} / \mathrm{M}$ & 0.099 & 0.054 \\
\hline $\mathrm{C} / \mathrm{M}$ & 0.000 & 0.191 \\
\hline$\underline{\mathrm{N}}$ & 1005 & 4063 \\
\hline
\end{tabular}

Note: Only the relative productivity coefficients are presented for the production functions. 
Table 9: Descriptive Statistics for the 1900 Census of Manufactures

Mean

Total for Industry/State Cell

Establishments

Average Per Establishment

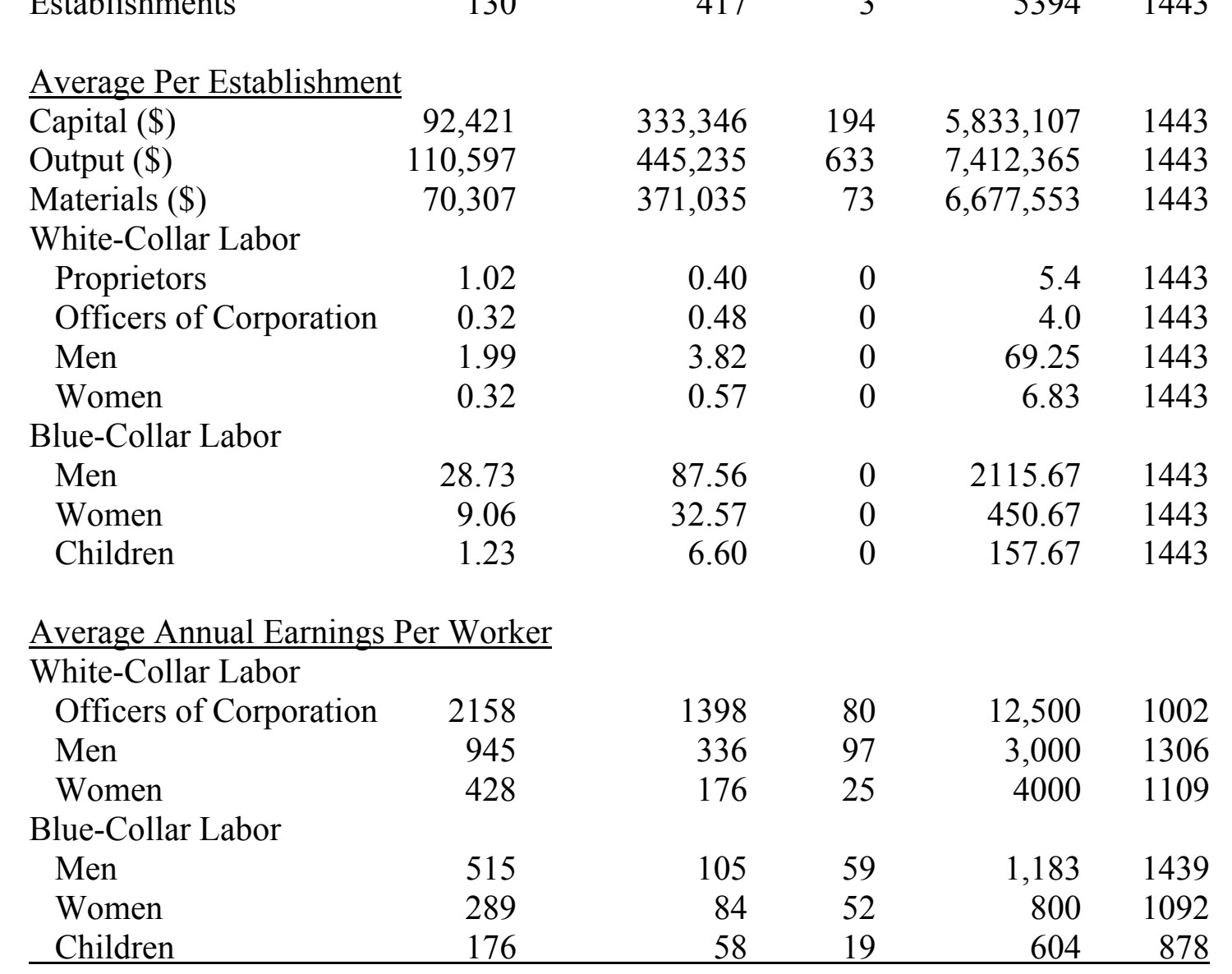

Std.Dev.

417

3

$5394 \quad 1443$

Min

$\operatorname{Max}$

$\mathrm{N}$

30

Average Annual Earnings Per Worker

White-Collar Labor

Officers of Corporation

Men

1398

1002

$\begin{array}{rrrr}336 & 97 & 3,000 & 1306 \\ 176 & 25 & 4000 & 1109\end{array}$

Blue-Collar Labor

Men

289

19

604 
Table 10: Production Functions for 1900

\begin{tabular}{|c|c|c|c|c|}
\hline \multirow{2}{*}{$\frac{\text { Parameter }}{\text { Constant }}$} & \multicolumn{2}{|c|}{ Translog } & \multicolumn{2}{|c|}{ Cobb Douglass } \\
\hline & $\begin{array}{c}6.847 \\
(0.460)\end{array}$ & $\begin{array}{c}7.000 \\
(0.464)\end{array}$ & $\begin{array}{c}3.285 \\
(0.096)\end{array}$ & $\begin{array}{c}3.328 \\
(0.097)\end{array}$ \\
\hline$a_{K}$ & $\begin{array}{c}0.428 \\
(0.116)\end{array}$ & $\begin{array}{c}0.378 \\
(0.111)\end{array}$ & $\begin{array}{c}0.139 \\
(0.010)\end{array}$ & $\begin{array}{c}0.140 \\
(0.010)\end{array}$ \\
\hline $\mathrm{a}_{\mathrm{RM}}$ & $\begin{array}{c}-0.629 \\
(0.071)\end{array}$ & $\begin{array}{c}-0.600 \\
(0.069)\end{array}$ & $\begin{array}{c}0.530 \\
(0.007)\end{array}$ & $\begin{array}{c}0.527 \\
(0.007)\end{array}$ \\
\hline $\mathrm{a}_{\mathrm{WC}}$ & $\begin{array}{c}0.274 \\
(0.118)\end{array}$ & $\begin{array}{c}0.281 \\
(0.113)\end{array}$ & $\begin{array}{c}0.205 \\
(0.018)\end{array}$ & $\begin{array}{c}0.202 \\
(0.018)\end{array}$ \\
\hline$a_{B C}$ & $\begin{array}{c}0.706 \\
(0.087)\end{array}$ & $\begin{array}{c}0.714 \\
(0.085)\end{array}$ & $\begin{array}{c}0.173 \\
(0.008)\end{array}$ & $\begin{array}{c}0.173 \\
(0.008)\end{array}$ \\
\hline$a_{\mathrm{KK}}$ & $\begin{array}{c}-0.009 \\
(0.008)\end{array}$ & $\begin{array}{c}-0.003 \\
(0.008)\end{array}$ & & \\
\hline $\mathrm{a}_{\mathrm{RMRM}}$ & $\begin{array}{c}0.082 \\
(0.005)\end{array}$ & $\begin{array}{c}0.083 \\
(0.005)\end{array}$ & & \\
\hline $\mathrm{a}_{\mathrm{WCWC}}$ & $\begin{array}{c}0.049 \\
(0.010)\end{array}$ & $\begin{array}{c}0.050 \\
(0.010)\end{array}$ & & \\
\hline $\mathrm{a}_{\mathrm{BCBC}}$ & $\begin{array}{c}0.057 \\
(0.008)\end{array}$ & $\begin{array}{c}0.063 \\
(0.008)\end{array}$ & & \\
\hline $\mathrm{a}_{\mathrm{KRM}}$ & $\begin{array}{c}-0.018 \\
(0.010)\end{array}$ & $\begin{array}{l}-0.025 \\
(0.010)\end{array}$ & & \\
\hline $\mathrm{a}_{\mathrm{KWC}}$ & $\begin{array}{c}0.049 \\
(0.016)\end{array}$ & $\begin{array}{c}0.041 \\
(0.015)\end{array}$ & & \\
\hline $\mathrm{a}_{\mathrm{KBC}}$ & $\begin{array}{c}0.007 \\
(0.012)\end{array}$ & $\begin{array}{c}0.001 \\
(0.011)\end{array}$ & & \\
\hline $\mathrm{a}_{\mathrm{RMWC}}$ & $\begin{array}{c}-0.056 \\
(0.012)\end{array}$ & $\begin{array}{c}-0.047 \\
(0.011)\end{array}$ & & \\
\hline $\mathrm{a}_{\mathrm{RMBC}}$ & $\begin{array}{c}-0.084 \\
(0.007)\end{array}$ & $\begin{array}{c}-0.082 \\
(0.007)\end{array}$ & & \\
\hline $\mathrm{a}_{\mathrm{WCBC}}$ & $\begin{array}{c}-0.069 \\
(0.014)\end{array}$ & $\begin{array}{l}-0.070 \\
(0.013)\end{array}$ & & \\
\hline$b_{1}$ & $\begin{array}{c}0.255 \\
(0.087)\end{array}$ & $\begin{array}{c}0.202 \\
(0.073)\end{array}$ & $\begin{array}{c}1.169 \\
(0.272)\end{array}$ & $\begin{array}{c}1.194 \\
(0.274)\end{array}$ \\
\hline$b_{2}$ & $\begin{array}{c}0.893 \\
(0.327)\end{array}$ & $\begin{array}{c}0.840 \\
(0.322)\end{array}$ & $\begin{array}{c}1.015 \\
(0.398)\end{array}$ & $\begin{array}{c}0.979 \\
(0.391)\end{array}$ \\
\hline$b_{3}$ & $\begin{array}{c}1.869 \\
(0.412)\end{array}$ & $\begin{array}{c}1.613 \\
(0.376)\end{array}$ & $\begin{array}{c}1.379 \\
(0.500)\end{array}$ & $\begin{array}{c}1.046 \\
(0.453)\end{array}$ \\
\hline $\mathrm{b}_{4}$ & $\begin{array}{c}0.563 \\
(0.051)\end{array}$ & $\begin{array}{c}0.575 \\
(0.049)\end{array}$ & $\begin{array}{c}0.489 \\
(0.075)\end{array}$ & $\begin{array}{c}0.512 \\
(0.077)\end{array}$ \\
\hline$b_{5}$ & $\begin{array}{c}-0.405 \\
(0.286)\end{array}$ & $\begin{array}{c}-0.404 \\
(0.285)\end{array}$ & $\begin{array}{c}-0.659 \\
(0.380)\end{array}$ & $\begin{array}{c}-0.644 \\
(0.402)\end{array}$ \\
\hline
\end{tabular}




\begin{tabular}{lcccc} 
State Dummies & & Yes & & Yes \\
Wage Ratio & & & & \\
Officers/MWC & 2.28 & 2.28 & 2.28 & 2.28 \\
p-value & 1.00 & 1.00 & 1.00 & 1.00 \\
& & & & \\
FWC/MWC & 0.45 & 0.45 & 0.45 & 0.45 \\
p-value & 0.00 & 0.00 & 0.03 & 0.10 \\
W/M & & & & \\
p-value & 0.56 & 0.56 & 0.56 & 0.56 \\
& 0.48 & 0.39 & 0.83 & 0.74 \\
C/M & & & & \\
p-value & 0.34 & 0.34 & 0.34 & 0.34 \\
& 1.00 & 1.00 & 1.00 & 0.94 \\
$\mathrm{R}^{2}$ & & & & \\
$\mathrm{~N}$ & 0.988 & 0.989 & 0.982 & 0.983 \\
& 1443 & 1443 & 1443 & 1443 \\
\hline
\end{tabular}

Table 11: Tests of Wage Discrimination for the 2002 Census of Manufactures

\begin{tabular}{ccccc} 
& \multicolumn{3}{c}{$\begin{array}{c}\text { Estimated } \\
\text { Productivity }\end{array}$} & R-value \\
\hline $\begin{array}{c}\text { Two Types of Labor } \\
\text { Female/Male }\end{array}$ & 0.717 & 0.835 & 0.006 & 0.00 \\
& & & & \\
Six Types of Labor & & & & \\
$\mathrm{M}_{\mathrm{Y}} / \mathrm{M}_{\mathrm{M}}$ & 0.617 & 0.901 & 0.010 & 0.00 \\
$\mathrm{M}_{\mathrm{o}} / \mathrm{M}_{\mathrm{M}}$ & 1.157 & 0.994 & 0.013 & 1.00 \\
$\mathrm{~F}_{\mathrm{Y}} / \mathrm{M}_{\mathrm{M}}$ & 0.515 & 0.762 & 0.011 & 0.00 \\
$\mathrm{~F}_{\mathrm{M}} / \mathrm{M}_{\mathrm{M}}$ & 0.693 & 0.816 & 0.009 & 0.00 \\
$\mathrm{~F}_{\mathrm{O}} / \mathrm{M}_{\mathrm{M}}$ & 0.715 & 0.823 & 0.014 & 0.00 \\
$\mathrm{~F}_{\mathrm{Y}} / \mathrm{M}_{\mathrm{Y}}$ & & & & \\
$\mathrm{F}_{\mathrm{O}} / \mathrm{M}_{\mathrm{O}}$ & 0.835 & 0.846 & & \\
\hline
\end{tabular}

Number of observations: $>100,000$.

"p-value" is the $p$-value for a one-tail test of the null hypothesis $b \geq$ wage ratio. Wage discrimination occurs if $b>$ wage ratio, so rejection of the null is evidence of discrimination. 


\section{Table 12: Estimates of the Female-to-Male Ratio}

\begin{tabular}{|c|c|c|c|c|c|c|}
\hline & $\begin{array}{r}1870 \\
\text { Children } \\
\text { w/ Women } \\
\end{array}$ & $\begin{array}{r}1870 \\
\text { Children } \\
\text { w/ Men } \\
\end{array}$ & $\begin{array}{r}1880 \\
\text { Children } \\
\text { w/ Women } \\
\end{array}$ & $\begin{array}{r}1880 \\
\text { Children } \\
\text { w/ Men } \\
\end{array}$ & $\begin{array}{r}1900 \\
\text { Children } \\
\text { w/ Women } \\
\end{array}$ & $\begin{array}{r}1900 \\
\text { Children } \\
\text { w/Men } \\
\end{array}$ \\
\hline \multicolumn{7}{|c|}{ Production Function } \\
\hline$b_{1}$ & $\begin{array}{c}0.362 \\
(0.079)\end{array}$ & $\begin{array}{c}0.522 \\
(0.131)\end{array}$ & $\begin{array}{c}0.717 \\
(0.052)\end{array}$ & $\begin{array}{c}0.730 \\
(0.064)\end{array}$ & $\begin{array}{c}0.638 \\
(0.055)\end{array}$ & $\begin{array}{r}0.679 \\
(0.062)\end{array}$ \\
\hline $\mathrm{R}^{2}$ & 0.94 & 0.94 & 0.95 & 0.95 & 0.99 & 0.99 \\
\hline
\end{tabular}

\section{Wage Equation}

\begin{tabular}{|c|c|c|c|c|c|c|}
\hline Constant & $\begin{array}{c}5.541 \\
(0.023)\end{array}$ & $\begin{array}{c}5.499 \\
(0.022)\end{array}$ & $\begin{array}{c}5.476 \\
(0.011)\end{array}$ & $\begin{array}{c}5.458 \\
(0.010)\end{array}$ & & \\
\hline $\begin{array}{l}\text { Percent } \\
\text { Women }\end{array}$ & $\begin{array}{c}-0.542 \\
(0.100)\end{array}$ & $\begin{array}{c}-0.078 \\
(0.130)\end{array}$ & $\begin{array}{c}-0.382 \\
(0.050)\end{array}$ & $\begin{array}{c}-0.210 \\
(0.060)\end{array}$ & & \\
\hline $\mathrm{R}^{2}$ & 0.02 & 0.00 & 0.01 & 0.00 & & \\
\hline \multicolumn{7}{|c|}{ Wage Ratios } \\
\hline $\mathrm{F} / \mathrm{M}$ & $\begin{array}{c}0.58 \\
(0.06)\end{array}$ & $\begin{array}{c}0.93 \\
(0.12)\end{array}$ & $\begin{array}{c}0.68 \\
(0.03)\end{array}$ & $\begin{array}{c}0.81 \\
(0.05)\end{array}$ & 0.47 & 0.54 \\
\hline p-value & 0.03 & 0.02 & 0.32 & 0.58 & 0.00 & 0.01 \\
\hline $\mathrm{N}$ & 1888 & 1888 & 7243 & 7243 & 1443 & 1443 \\
\hline
\end{tabular}

$\mathrm{p}$-value is for a test of the nul hypothesis that the productivity ratio and wage ratio are equal. 
Table 13: A Summary of Studies of Female-Male Productivity Differences

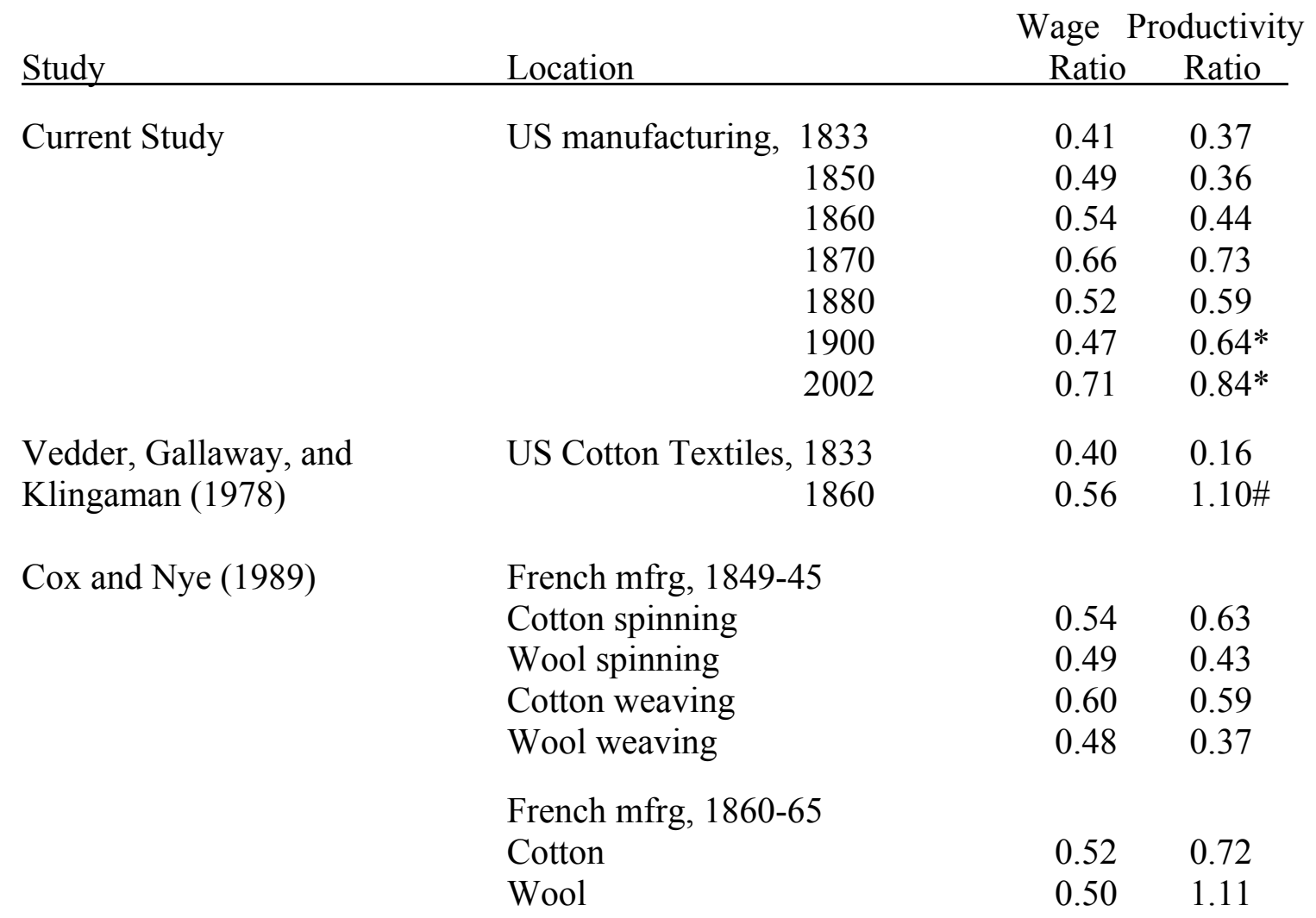

McDevitt, Irwin, and Inwood (2009)

Leonard (1984)

Haegeland and Klette (1999)
Canadian manufacturing, 1870

US manufacturing, 1966 1977

Norwegian mfrg., 1986-93
$0.38 \quad 0.49 *$

$0.53 \quad 0.75^{*}$

$0.54 \quad 1.01 *$

$0.82 \quad 0.83$

Hellerstein and Neumark (1999) Israeli mfrg., 1989

$0.77 \quad 0.82$

Hellerstein, Neumark, Troske

US 1990

$0.55 \quad 0.84 *$

$*=$ productivity ratio is significantly above the wage ratio, indicating wage discrimination

$\#=$ evidence on wage discrimination is mixed; half of the specifications show evidence of wage discrimination 
Figure 1: Trends in Female-Male Productivity and Wage Ratio

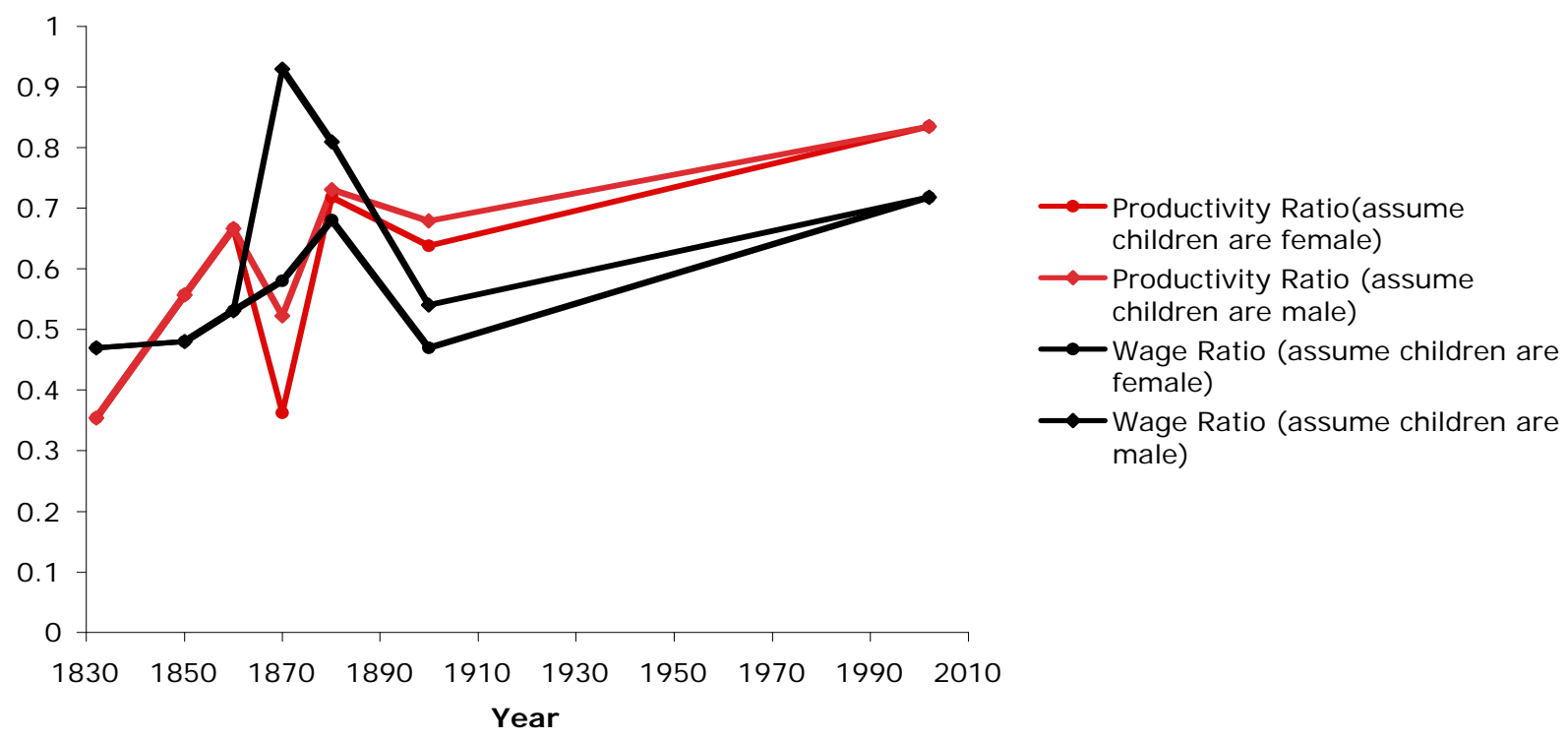

